\title{
Residential environment and breast cancer incidence and mortality: a systematic review and meta-analysis
}

Tomi F Akinyemiju', Jeanine M Genkinger ${ }^{1,2}$, Maggie Farhat ${ }^{1}$, Adrienne Wilson ${ }^{3}$, Tiffany L Gary-Webb ${ }^{1,4^{*}}$ and Parisa Tehranifar ${ }^{1,2^{*}}$

\begin{abstract}
Background: Factors beyond the individual level such as those characterizing the residential environment may be important to breast cancer outcomes. We provide a systematic review and results of meta-analysis of the published empirical literature on the associations between breast cancer risk and mortality and features of the residential environment.

Methods: Using PRISMA guidelines, we searched four electronic databases and manually searched the references of selected articles for studies that were published before June 2013. We selected English language articles that presented data on adult breast cancer incidence or mortality in relation to at least one area-based residential (ABR) independent variable.

Results: We reviewed 31 eligible studies, and observed variations in ABR construct definition and measurement, study design, and analytic approach. The most common ABR measures were indicators of socioeconomic status (SES) (e.g., income, education, summary measures of several SES indicators or composite SES). We observed positive associations between breast cancer incidence and urbanization (Pooled RR for urban vs. rural: 1.09. 95\% Cl: 1.01, 1.19), ABR income (Pooled RR for highest vs. lowest ABR income: 1.17, 95\% Cl: 1.15, 1.19) and ABR composite SES (Pooled RR for highest vs. lowest ABR composite SES: 1.25, 95\% Cl: 1.08, 1.44). We did not observe consistent associations between any ABR measures and breast cancer mortality.
\end{abstract}

Conclusions: The findings suggest modest positive associations between urbanization and residential area socioeconomic environment and breast cancer incidence. Further studies should address conceptual and methodological gaps in the current publications to enable inference regarding the influence of the residential environment on breast cancer.

Keywords: Breast cancer epidemiology, Residential environment, Socio-economic status, Mortality, Urbanization

\section{Background}

Research on breast cancer epidemiology has traditionally focused on investigating genetic, biomedical and individuallevel behavioral factors. However, in the last several decades, researchers have begun to also consider the role of the environment in which individuals reside (residential environment). The residential environment as a determinant of health was highlighted in the 1979 Surgeon General

\footnotetext{
*Correspondence: tgary@pitt.edu; pt140@columbia.edu

'Department of Epidemiology, Columbia University Mailman School of Public Health, New York, NY, USA

Full list of author information is available at the end of the article
}

report as part of a comprehensive approach to disease prevention [1], and research in this area further intensified following the 2010 Healthy people report [2].

The residential environment may play a role in breast cancer incidence and mortality through the geographic distribution of breast cancer risk factors, access to quality and timely healthcare resources and medical treatment, as well as through psychosocial pathways involving stress and social support [3-5]. For example, parity, lack of breastfeeding and increased alcohol use are associated with area level characteristics such as neighborhood poverty and access to healthcare [6-9]. The residential 
environment may also promote and/or hinder utilization of or access to early detection and treatment services $[10,11]$, thereby affecting breast cancer mortality and survival. For instance, access to routine screening such as mammography facilities increases the chance that cancer is detected at early stages for which treatment is most effective, and access to healthcare increases the likelihood of adequate treatment $[12,13]$. Thus, understanding the association between features of the residential environment and breast cancer outcomes may provide insight into factors relevant to risk reduction, adequate screening and timely treatment, and guide primary, secondary and tertiary prevention efforts.

Different aspects of the residential environment are captured through area-based residential (ABR) measures, most often constructed by aggregating or mathematically summarizing the characteristics of individuals residing within an area (e.g., proportion of residents living below federally defined poverty, mean income level of residents in an area). Although these ABR measures may be used as proxies for individual-level factors when such information is lacking, they may also indicate features of residential environment that are associated with an outcome differently or independently of individual-level factors. ABR measures may also be based on the properties of an area that do not simply summarize characteristics of individuals, and thus, have no equivalent measure at the individual level (e.g., population density or urbanization) [14]. Multiple studies have assessed ABR measures in relation to breast cancer incidence and outcomes. However, to our knowledge, no review of the literature on ABR measures and breast cancer has been previously published. The purpose of this review is to: 1) provide a comprehensive synthesis of the published literature on the associations between features of residential environments, measured at the area level, and breast cancer incidence and mortality; and 2) conduct meta-analysis of results, as appropriate. Additionally, we will describe commonalities and differences in the research findings across the two breast cancer outcomes and across racial/ ethnic populations, and identify gaps in the literature.

\section{Methods for evidence acquisition and synthesis Search strategy}

We employed established PRISMA guidelines for conducting systematic reviews in health [15]. Given that search terms are not fully developed or systematically used, we chose a broad strategy by searching for many general key words in multiple electronic databases. We also used search terms based on previously published studies and added other relevant terms as appropriate. We searched the electronic databases of PubMed, CINAHL, PsychInfo and Web of Science (WOS) using the term "breast cancer" and any of the following key words: neighborhood, neighbourhood, county, census, residential, residence, area-based, geograph*, environment", walk*, multilevel, multi-level, context*, hierarchical, community. We limited our search to studies of adult human subjects that were published in English. The search period for article inclusion was from database inception to June 30, 2013.

\section{Eligibility criteria}

Eligible articles met all of the following criteria: 1) were published in English; 2) reported results from analysis of original data (including population-based cancer registries); 3) used at least one area-based residential measure as an independent variable in analysis, including both compositional, aggregated (based on characteristics or the aggregation of characteristics of individuals residing in an area) and contextual measures (characteristics of a defined geographic area); 4) used at least one individuallevel covariate in addition to an $A B R$ variable; and 5) evaluated female invasive breast cancer incidence/risk or mortality as the outcome. Studies that only examined trends over time, mortality among individuals with breast cancer, and ecological data (i.e., aggregated vs. individual-level outcome data) were excluded.

\section{Selection strategy}

Two authors (PT, TA) independently reviewed study titles, abstracts and full text articles. We reviewed abstracts for study titles selected by at least one reviewer, and reviewed abstracts and full text articles that were selected by both reviewers. Another author (TGW) adjudicated when consensus could not be reached. Figure 1 presents a flowchart of the study selection process and results. We reviewed study titles for 13,160 articles that were identified through the previously mentioned search strategy, and selected 439 articles for the review of the abstracts. Most of the excluded articles either assessed non-cancer outcomes, cancers other than breast cancer, or outcomes such as stage of presentation or treatment, examined trends over time, or compared geographic areas without assessing a specific ABR measure. We selected 39 articles for full text review from the reviewed abstracts. We reviewed 50 additional abstracts identified through manual review of the references of the 39 selected full text articles, and selected an additional 24 articles for full text review. Of the total 63 full text articles reviewed, 31 articles were eligible for data abstraction, and 32 articles were excluded as they examined non-eligible outcomes (e.g., other cancer sites, survival in breast cancer cases; $n=9$ ), lacked any area-based independent (exposure) variable $(\mathrm{n}=8)$, did not present relevant data $(\mathrm{n}=8)$, did not involve original research $(n=3)$, or presented only ecological results $(n=4)$. 


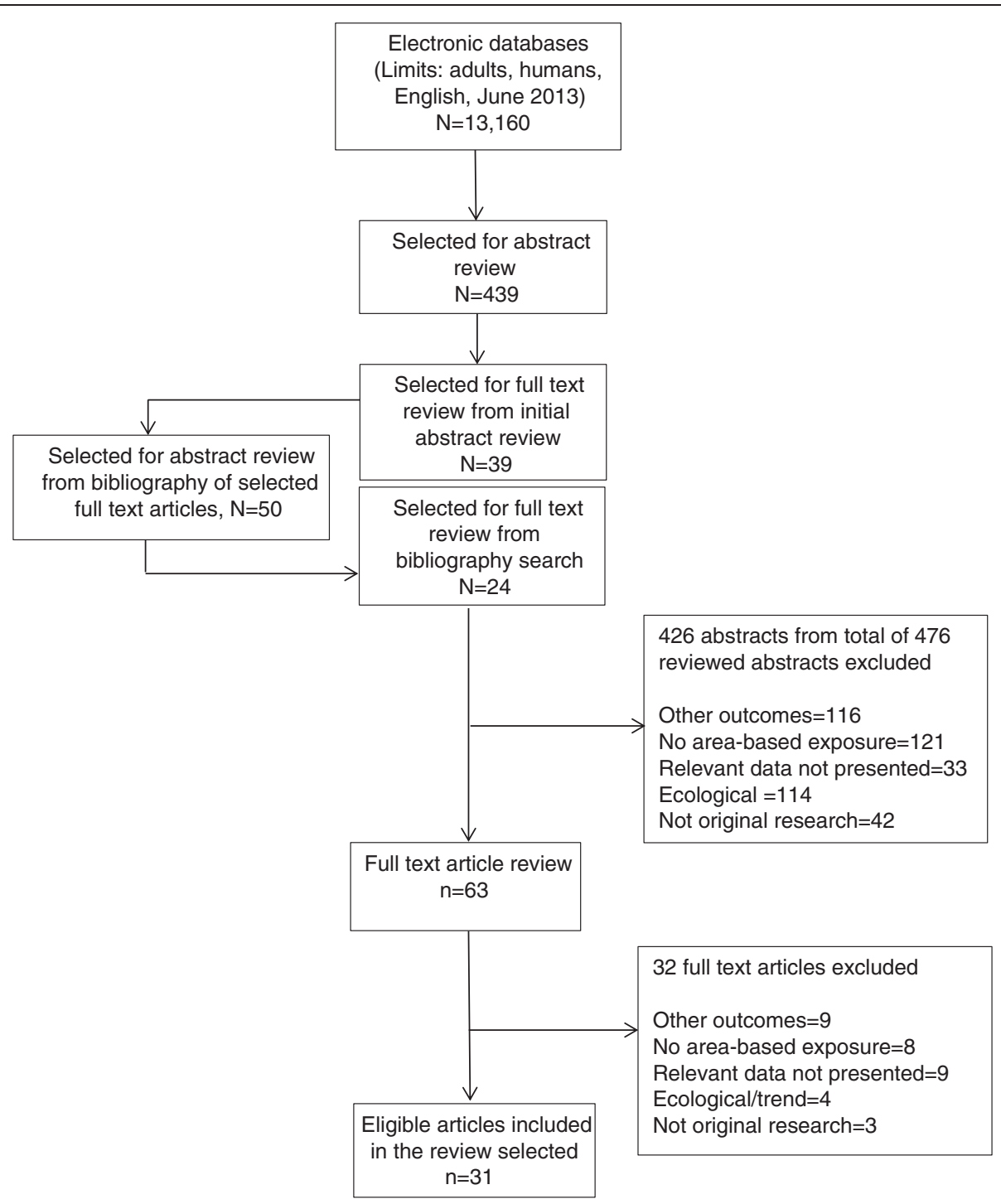

Figure 1 Publication search and selection results.

\section{Data extraction and synthesis}

One author (MF) abstracted data from the selected articles into an electronic database, and two authors (PT, TA) independently verified the coded information against the original articles. All three abstractors met to resolve any inconsistencies by consensus. We extracted data on study characteristics and relevant results for all ABR measures. The study characteristics included the country and region of the study, study design, sample size, data sources, measurement of the residential factors, and age and racial/ethnic distribution if reported. We also retrieved information on the main statistical methods and covariates. Finally, for the extreme two levels of categorical ABR measures (e.g., highest and lowest income levels), we extracted measures of frequency (e.g., rates), or relative measures of association (e.g., relative rate $[R R]$, odds ratio $[\mathrm{OR}]$, hazards rate ratios $[\mathrm{HR}]$ ) and 95\% confidence interval $(\mathrm{CI})$, and $\mathrm{p}$-values for linear trend where available.

\section{Statistical analysis}

When measures of association were not presented in the manuscript, we calculated rate ratios using reported ageadjusted rates comparing the highest to the lowest category of each ABR measure [4,16-23]; otherwise, ratio measures were presented for the contrast reported in the original articles. If rates were stratified (e.g. by race/ ethnicity), we calculated the rate ratios for each stratum. Due to our interest in understanding racial differences in associations between ABR variables and breast cancer, 
we present data for un-stratified associations as well as race-stratified associations. If only stratified results were reported, we present rate ratios for the first stratification level.

To be eligible for inclusion in meta-analysis, we required the same ABR construct in at least 2 studies in relation to the same outcome (i.e., incidence/risk or mortality) within the same stratification level, and the studies needed to have sufficient data to calculate a risk estimate and standard error or confidence intervals. We re-calculated the estimates presented in some of the articles to correspond to the same comparison (e.g., estimates presented comparing the lowest to highest income category were re-calculated for the contrast to correspond to the highest versus lowest income category). Based on these criteria, the ABR constructs included in the meta-analysis were ABR measures of education, income, poverty, composite SES and urbanization in relation to breast cancer incidence, and urbanization in relation to breast cancer mortality. If multiple studies presented results that were based on the same dataset for the study period and ABR construct were the same, the study with the larger sample size was included in the meta-analysis. We estimated summary rate ratios comparing the two extreme categories of $\mathrm{ABR}$ measures in relation to breast cancer incidence using randomeffects models [24]. We calculated the Q-statistic to test for between-studies heterogeneity, and used the $\mathrm{I}^{2}$ statistic to calculate the proportion of variation between studies due to heterogeneity. We assessed potential publication bias via inspection of funnel plots and Egger's test for small-study effects. As the results of the funnel plots and Egger's test were consistent, we only present the p-values of the Egger's test for the meta-analysis. We conducted sensitivity analyses of the meta-analysis results when more than two studies were available (influence analysis), and when more than 4 studies were available (meta-regression [25]). All statistical analyses were performed using STATA version 12.0 (Stata Corp, College Station, Texas USA).

\section{Results}

Of the 31 articles that fulfilled our selection criteria [4,16-23,26-47], 24 examined breast cancer incidence or risk only [16-21,27,28,30-35,37,39-47], four examined breast cancer mortality only $[26,29,36,38]$, and three articles examined both incidence/risk and mortality $[4,22,23]$ (Table 1). The number of published articles increased steadily over the past several decades, with only one article in each decade of the 1970s [26] and 1980s [17], 9 articles in the 1990s $[16,20-23,30,33,34,39], 11$ in the 2000s $[4,18,19,28,32,35,40-42,46,47]$, and 9 in 2010 through June $2013[27,29,31,36-38,43,45,47]$. About $75 \%(n=23)$ of the published articles were based in the United States (U.S.), including one article that examined data from both the U.S. and Canada [4,16-21,26,28,31-37,39-43,46,47]; an additional two articles were based in Canada [27,30]. Of the remaining articles, two were conducted in Australia $[23,29]$, two in the United Kingdom (U.K.) [22,44], one in Italy [45] and one in Switzerland [38]. Detailed descriptions of each article and sample characteristics are presented in Table 2.

\section{Data sources}

The most common source for breast cancer data included national and state cancer registries. Of the 23 U.S.-based studies, 8 studies utilized U.S. Surveillance Epidemiology and End Results (SEER) registry data $[4,16,20,28,32,35,36,43]$, and 9 studies utilized regional or state cancer registry data [21,31-33,39-41,46,47]; the remaining studies used data from individual research studies (two case-control $[42,46]$, and two cohort studies $[37,40])$. Data for the ABR measures used in these studies were mostly from national census surveys. The majority of the U.S. studies used data from California [31,32,39-41,47], SEER regions (these include Atlanta, Connecticut, Detroit, Hawaii, Iowa, New Mexico, SanFrancisco-Oakland, Seattle-Puget Sound, Utah, Los Angeles, San Jose-Monterey, rural Georgia, the Alaska Native Tumor Registry, Greater California, Kentucky, Louisiana, and New Jersey) $[4,16,20,32,35,36,43]$, and North American Association of Central Cancer Registries (NAACCR) data [19]. Other areas included New York [21], North Carolina [18], Massachusetts [46] and Wisconsin [42]. Other U.S. studies used nationally representative survey data (National Longitudinal Mortality Study and Third National Cancer Survey [17,28]), and one nationally recruited study population [37]. All Canadian (3 studies) $[27,30,35]$ and U.K. studies (2 studies) $[22,44]$ used cancer registry data to identify breast cancer cases. Other studies from Australia (two cohort studies) [23,29], Italy (one study) [45] and Switzerland (one study) [38] obtained breast cancer data from individual research studies.

\section{Study design and sample characteristics}

All studies analyzed breast cancer data in females with varying age inclusion criteria ranging from ages 15 and older to ages 70-75 years. Racial distribution of the analytic samples was not consistently reported, with only 13 studies, all based in the U.S., reporting the racial distribution of the study population [17-20,28,31,33,34,36, $37,39,43,47]$. Of these, one study each included only Hispanic women [31], only African-American women [37], and only white women [39]. Studies that included more than one racial group were comprised of predominantly white women (making up between 69\% and 98\% of the study population). Most studies (25 studies), utilized data with a cross-sectional design [4,16-23,26-28, 
Table 1 Summary description of studies

\begin{tabular}{|c|c|c|c|}
\hline & \multirow{2}{*}{$\begin{array}{l}\text { Total number } \\
\text { of studies } \\
(n=31)\end{array}$} & \multicolumn{2}{|c|}{$\begin{array}{l}\text { Number of studies } \\
\text { by breast cancer outcome }\end{array}$} \\
\hline & & $\begin{array}{l}\text { Incidence/risk } \\
(n=27)\end{array}$ & $\begin{array}{l}\text { Mortality } \\
(n=7)\end{array}$ \\
\hline \multicolumn{4}{|l|}{ Publication years } \\
\hline $2010-2013^{*}$ & 9 & 6 & 3 \\
\hline 2000-2009 & 11 & 11 & 1 \\
\hline 1990-1999 & 9 & 9 & 2 \\
\hline 1980-1989 & 1 & 1 & 0 \\
\hline 1970-1979 & 1 & 0 & 1 \\
\hline \multicolumn{4}{|l|}{ Study design } \\
\hline Cross-sectional & 25 & 23 & 5 \\
\hline Longitudinal & 4 & 2 & 2 \\
\hline Case-control & 2 & 2 & 0 \\
\hline \multicolumn{4}{|l|}{ Country } \\
\hline U.S.土 & 23 & 21 & 3 \\
\hline Canada \pm & 3 & 3 & 0 \\
\hline U.K. & 2 & 2 & 1 \\
\hline Australia & 2 & 1 & 2 \\
\hline Italy & 1 & 1 & 0 \\
\hline Switzerland & 1 & 0 & 1 \\
\hline \multicolumn{4}{|l|}{ Geographic unit } \\
\hline Census tract & 8 & 8 & 0 \\
\hline Census block group & 8 & 8 & 0 \\
\hline County & 5 & 4 & 3 \\
\hline Zip/Postal code & 3 & 3 & 0 \\
\hline Other & 7 & 9 & 4 \\
\hline \multicolumn{4}{|l|}{ Racial composition } \\
\hline White/European & 11 & 10 & 1 \\
\hline African American/Black & 9 & 8 & 1 \\
\hline Hispanic & 7 & 7 & 0 \\
\hline Asian/Pacific Islanders & 5 & 5 & 0 \\
\hline $\begin{array}{l}\text { American Indian/Native } \\
\text { Alaskan }\end{array}$ & 1 & 1 & 0 \\
\hline Other & 2 & 2 & 0 \\
\hline No data & 18 & 16 & 6 \\
\hline
\end{tabular}

"Publications assessed until June 2013.

$\psi_{3}$ publications assessed both breast cancer incidence and mortality outcomes. \pm 1 publication was conducted in the US and Canada.

30-36,39,41,43-45,47], two were case-control studies $[42,46]$, and four were cohort studies $[29,37,38,40]$. In addition to individual-level demographic covariates such as age and race/ethnicity, 7 studies included individuallevel risk factors for breast cancer such as family history of breast cancer, mammography use, parity, lactation, menarche, physical activity, alcohol intake, body mass index, hormone replacement use, oral contraceptive use and menopausal status [36-38,40,42,45,46].

\section{Area-Based Residential (ABR) measures}

The majority of ABR measures captured different aspects of socioeconomic environment including education $[16,17,39,43]$, income $[16,17,26,27,35,39]$, poverty $[4,19,20,30,39,43,46]$, summary measures of several indicators of SES (hereafter, composite SES) [22,23,31-34,37, $38,41,42,44-47]$ and occupational class [20,39]. Income and education measures were respectively based on median family or household income, and median years of school completed or percent of the population with college or high school degree. Poverty measures included the proportion of the population living below the federally defined poverty level as determined by the annual household size adjusted income. Occupational class was assessed based on the proportion of adults employed in working class occupations [20,39]. Measures of composite SES were created using a combination of variables such as income, education, occupation, and housing characteristics. In the U.S. studies, such composite measures varied in their definitions and component variables; however, the two U.K. studies were consistent in the use of the Townsend Index of Social Deprivation, a summary residential deprivation score defined by percent of economically active residents aged 16-59 who are unemployed, percentage of private households that do not possess a car, percentage of private households that are not owner-occupied and the percentage of private households with more than one person per room [48]. Relative income was assessed as the median household income for each population decile divided by median household income of the poorest decile [35,45]. Other ABR measures included urbanization and Hispanic enclave. Urbanization was based on residence in rural versus urban areas, or metropolitan versus nonmetropolitan areas, as defined by population density $[18,19,21,28,29,36,40-43]$. Hispanic enclave was defined as the proportion of Hispanic, Spanish speaking and linguistically isolated individuals within the area [31].

Studies of breast cancer incidence included ABR measures of education in 4 studies $[16,17,39,43]$, income or income inequality in 6 studies $[16,17,27,35,39,45]$, poverty in 7 studies $[4,19,20,30,39,43,46]$, composite SES in 13 studies [22,23,31-34,37,41,42,44-47], occupational class in 2 studies [20,39], urbanization in 8 studies [18,19,21,28,40-43], and Hispanic enclave in one study [31]. Studies of breast cancer mortality included ABR measures of income in 1 study [26], poverty in 1 study [4], composite SES in 3 studies $[22,23,38]$, and urbanization in 2 studies $[29,36]$.

\section{Geographic unit}

Census tract $[16,17,30,32,34,35,42,45]$ and census block group $[20,31,33,37,39,41,46,47]$ levels were the most common geographic unit, used in 8 studies each. County level measures were used in 6 studies $[4,18,19,26,36,43]$, 
Table 2 Characteristics of studies of residential environment and breast cancer risk or incidence

\section{Author, year (location) Individual-level data source;} area level data source

[26]Blot, 1977

(United States)

[17]Devesa, 1980

(United States)

[20]Krieger, 1990

(United States)

[16]Baquet, 1991

(United States)

[23]Williams, 1991 (Australia)

[21]Nasca, 1992 (United States)

[22]Pollock, 1997 (United Kingdom)

Metropolitan Toronto Census tract

The Los Angeles County Surveillance Cross-sectional; Females; $\geq 15$ Los Angeles County Program 1979-1992: US Census 1970, years old: $n=82,453$ cases: $77.9 \%$

\section{unit}

Contiguous US; county

18 US Standard

Metropolitan Statistica Areas; Census Tracts

San Francisco Bay Area Census block group

San Francisco/Oakland Atlanta, Detroit; Census tract

Melbourne; Local government area

New York state exclusive of New York City; Minor civil divisions

South Thames: Enumeration distric (United States)
1980, 1990
Census tract
Main area based measures (measurement)

Outcome

Income (Median family income, categorized

into 2 groups: $<50 \%,>50 \%$ by region and

population-size)

Education (Median years of education

categorized into 5 groups for Whites: $<10$

$10-10.9,11-11.9,12-12.9$, and $\geq 13$ years; categorized into 3 groups for blacks: $<10$,

10-10.9, and $\geq 11$ years) Income (Median family income categorized into 5 groups for Whites: $<\$ 9,000, \$ 9,000-10,999, \$ 11,000-12,999, \$ 13,000-$ $14,999, \geq \$ 15,000$; and categorized into 3 groups for blacks: $<\$ 5,000, \$ 5000-6,999, \geq \$ 7,000)$

Occupational class composition (\% employed in Incidence "working class" occupations, categorized into 2 groups $\leq 66 \%$ and $>66 \%$ in working class

occupations): Poverty (\% living below poverty, categorized into two groups ( $\geq 20 \%$ and $<20 \%$ )

Education (Median years of education,

Incidence

categorized into 4 groups: <high school, high

school graduates, some college, at least 4 years of college) Income (Median family income, categorized into 4 groups: $<\$ 15,000, \$ 15,000-$ $24,999, \$ 25,000-29,999, \geq \$ 30,000)$

Composite SES (Based on occupational status, income, educational attainment, family instability, persons living in low standard housing likely to have difficulty with English categorized into deciles)

Urbanization (Population density: [persons/ square miles], categorized into quinitles

Composite SES "Townsend Index of Socia Deprivation" (based on \% unemployed, \% private household lacking a car, \% private household not owner occupied, \% private household subject to overcrowding; categorized into deciles)

Poverty (annual household income adjusted for Incidence household size, categorized into low $(\geq 23 \%$

households below low-income cutoff) and high

( $<7 \%$ of households below criterion))

Composite SES (Based on weighted average educational attainment and median household income; categorized into quintiles) 
Table 2 Characteristics of studies of residential environment and breast cancer risk or incidence (Continued)

\begin{tabular}{lll}
\hline [39]Prehn, 1998 & Northern California cancer center's & Cross-sectional; Females; \\
(United States) & greater Bay Area cancer registry & $\mathrm{n}=22,757$ cases; 100\% white \\
& 1988-1992; US Census 1990 &
\end{tabular}$$
\text { San Francisco Bay Area }
$$

and 20 counties from

adjoining regions; Census

Education (\% with college education,

categorized into 2 groups: $\geq 45 \%$ vs. $<45 \%$ );

Incidence

Income (Median household income

categorized into 2 groups $\geq \$ 50000$ and

$<\$ 50000)$; Occupational Class (\% employed in

working class occupations, categorized into 2

groups $\leq 50 \%$ and $>50 \%$ working class); Poverty

(\% below poverty level, categorized into 2

groups $\leq 5 \%$ vs. $>5 \%)$

[33]Krieger, 1999

(United States)

Population-based cancer registry 1988-1992; US Census 1990

Cross-sectional; Females; $n=16,120$ cases; $78 \%$ white, $7 \%$ black, 7\% Hispanic, 8\% Asian

San Francisco Bay Area Census block group

Composite SES (Combination of occupational class (\% employed in "working class" and "professional" occupations) and poverty (\% below poverty level); categorized into 3 groups: 1) professional (non-poor and poor), 2) working class, non-poor, 3) working class, poor)

Ontario Cancer Registry (1989-1993); Cross-sectional SEER 1988-1992: Canadian Census

1991 and US Census 1990

States)

[40]Reynolds, 2004

(United States)

[42]Robert, 2004

(United States)

[18]Hall, 2005

(United States)

North Carolina State Registry

1995-1999; US Census 1990

The California Teachers Study cohort with annual linkage to the California Cancer Registry, baseline in 1995 with follow up through Dec 1999; US Census 1990

Population-based case control study 1988-1995. US Census 1990

Case-control; Females; 20-79 years old; $n=7,179$ cases, 7,488 controls

Cross-sectional; Females; 27,989 cases, $82 \%$ white, $18 \%$ non-white

Ontario, Canada; 9 SEER regions in US;

Enumeration area in

Canada and census tract in the U.S.

Prospective cohort; Females; 21

California; region

Income (Median household income,

categorized into deciles. Race-specific deciles in

the US for secondary analysis) Natural log of

relative income for regression

Urbanization (a priori specification of urban counties, categorized into San Francisco Bay area, Southern Coastal area, rest of California)

Wisconsin; Census trac and Zip code

Composite SES (Based on median income, \% adults below poverty, \% unemployed, \% college graduate, categorized into quintiles) Urbanization (Residence in census-defined "urban areas", categorized into 3 groups: 100\% rural, mixed rural/urban, 100\% urban)

North Carolina; County

Metropolitan areas (Urban Influence Code based on by adjacency or non-adjacency to a Metropolitan Area, and size of the largest communities, categorized into 3 groupsmetropolitan; non-metropolitan adjacent to metropolitan; non-metropolitan, nonadjacent to metropolitan areas)

Cross-sectional; Females: $\geq 20$ years old: 176,302 cases

California; Block group

Composite SES (Based on \% with college degree, median family income and \% employed in managerial/professional occupations, categorized into quartiles) Urbanization (Population size and density, categorized into 4 groups -urban suburban city, small town/rural)

Cross-sectional. Females: 154,083 San Francisco/ Oakland, cases

Composite SES (\% below poverty level and \% high income ho'useholds (defined as $\geq 4$ times 
Table 2 Characteristics of studies of residential environment and breast cancer risk or incidence (Continued)

\begin{tabular}{|c|c|c|}
\hline & $\begin{array}{l}\text { Massachusetts Cancer registry } \\
\text { 1978-1982, 1988-1992, 1998-2002/ } \\
\text { US Census 1980, 1990, 2000 }\end{array}$ & \\
\hline $\begin{array}{l}\text { [44]Shack, } 2008 \\
\text { (United Kingdom) }\end{array}$ & $\begin{array}{l}\text { English cancer registries 1998-2003; } \\
\text { UK Census } 2001 \text { and government } \\
\text { databases }\end{array}$ & $\begin{array}{l}\text { Cross-sectional; Females; 210,020 } \\
\text { cases }\end{array}$ \\
\hline $\begin{array}{l}\text { [46]Webster, } 2008 \\
\text { (United States) }\end{array}$ & $\begin{array}{l}\text { The Massachusetts Cancer Registry } \\
\text { 1987-1993; US Census 1980, } 1990\end{array}$ & $\begin{array}{l}\text { Case-control; Females; } 548 \text { cases, } \\
490 \text { controls }\end{array}$ \\
\hline $\begin{array}{l}\text { [28]Clegg, } 2009 \\
\text { (United States) }\end{array}$ & $\begin{array}{l}\text { National Longitudinal Mortality Study } \\
\text { and SEER, 1973-2001; US Census } \\
\text { 1970, 1980, 1990 }\end{array}$ & $\begin{array}{l}\text { Cross-sectional; Females; } \geq 25 \\
\text { years old; } 1739 \text { cases; } 78 \% \text { white, } \\
7 \% \text { black, } 4 \% \text { Mexican, } 1 \% \text { other } \\
\text { Hispanic, } 4 \% \text { Asian/Pacific } \\
\text { Islander, } 2 \% \text { other }\end{array}$ \\
\hline $\begin{array}{l}\text { [4] Harper, } 2009 \\
\text { (United States) }\end{array}$ & SEER 1987-2004; US Census 1990 & Cross-sectional \\
\hline $\begin{array}{l}\text { [19]Hausaer, } 2009 \\
\text { (United States) }\end{array}$ & $\begin{array}{l}\text { NAACCR Registries 1997-2004; } \\
\text { USDA } 2003\end{array}$ & $\begin{array}{l}\text { Cross-sectional; Females; } 50-74 \\
\text { years old; } 587,408 \text { cases; } 100 \% \\
\text { white }\end{array}$ \\
\hline $\begin{array}{l}\text { [29]Dobson, } 2010 \\
\text { (Australia) }\end{array}$ & $\begin{array}{l}\text { Australian Longitudinal Study on } \\
\text { Women's Health, baseline survey in } \\
1996 \text { with follow up through 2006; } \\
\text { The Australian Standard Geographic } \\
\text { Classification }\end{array}$ & $\begin{array}{l}\text { Longitudinal; Females; } 70-75 \\
\text { years at baseline; } 12,400 \text { with } \\
2,803 \text { breast cancer deaths }\end{array}$ \\
\hline $\begin{array}{l}\text { [31]Keegan, } 2010 \\
\text { (United States) }\end{array}$ & $\begin{array}{l}\text { The California Cancer Registry } \\
\text { 1988-2004; US Census } 2000\end{array}$ & $\begin{array}{l}\text { Cross-sectional; Females; } 12,563 \\
\text { cases; } 100 \% \text { Hispanic }\end{array}$ \\
\hline
\end{tabular}

Massachusetts; Census

tract

8 UK cancer registries: Postal code of residence

Cape Cod, Massachusetts: Census block group

11 SEER regions

SEER regions; County

29 population-based cancer registries in the North American Association of Central Cancer Registries (NAACCR); County

Australia

California/ Cross-sectiona Block groups averaged over census tracts (for SES)

Composite Hispanic Enclave (Based on \% linguistically isolated overall and who speak

Poverty (\% below poverty level, categorized into 4 groups: $<10 \%, 10-14 \%, 15-19 \%, \geq 20 \%$

Poverty (\% below poverty level, categorized into 3 groups: $<10 \%, 10-19 \%, \geq 20 \%)$

Urbanization (US Dept. of Agriculture codes and population size, categorized into urban, suburban and rural areas)

Area of residence (Road distance to the closest service center, a measure of population size) Spanish, speak limited English, speak limited

English and speak Spanish, \% recent immigrants, \% Hispanic, \% foreign-born) Composite SES (Based on income, occupation, and housing costs, categorized into quintiles) Combined SES and Hispanic Enclave (Combination of SES and Hispanic enclave, categorized into 4 groups: low SES-high enclave, high SES-low enclave, low SES-low enclave, high SES-high enclave)

Turin, Italy; Census tract Piedmont Cancer Registry, 1985-1999; years old; 9,203 cases Italian Census 197 houses without bath, $\%$ families with a single
Composite SES (Based on \% manual workers $\%$ with low education, $\%$ tenants, $\%$ living $\%$ in parent with children, and a crowding index categorized into quintiles) Relative Index of
Mortality

Incidence

Risk

Incidence mortality

Incidence

Incidence 


\begin{tabular}{|c|c|c|c|c|c|}
\hline & & & & $\begin{array}{l}\text { Inequality (Ratio of regression-based rates for } \\
\text { extreme points of the social hierarchy) }\end{array}$ & \\
\hline $\begin{array}{l}\text { [27]Borugian, } 2011 \\
\text { (Canada) }\end{array}$ & $\begin{array}{l}\text { The Canadian Cancer Registry } \\
\text { 1992-2004; Canadian Census 1991, } \\
\text { 1996, 2001, } 2006\end{array}$ & $\begin{array}{l}\text { Cross-sectional; Females; } \\
\geq 19 \text { years old; } 226,169 \text { cases }\end{array}$ & Canada; postal code & $\begin{array}{l}\text { Income (Average income per single person } \\
\text { equivalent in the enumeration area or } \\
\text { dissemination area, categorized into quintiles) }\end{array}$ & Incidence \\
\hline $\begin{array}{l}\text { [47]Yost, } 2001 \\
\text { (United States) }\end{array}$ & $\begin{array}{l}\text { The California Cancer Registry } \\
\text { 1988-1992 US Census } 1990\end{array}$ & $\begin{array}{l}\text { Cross-sectional; Females; } \\
\geq 15 \text { years old; } 97,227 \text { cases; } 80 \% \\
\text { white, } 6 \% \text { black, } 9 \% \text { Hispanic, } 5 \% \\
\text { Asian }\end{array}$ & $\begin{array}{l}\text { California; Census block } \\
\text { group }\end{array}$ & $\begin{array}{l}\text { Composite SES (Based on education index, } \\
\text { proportion with a blue-collar job, } \% \text { in work- } \\
\text { force without a job, median household income, } \\
\% \text { below } 200 \% \text { poverty level, median rent, me- } \\
\text { dian house value, categorized into quintiles) }\end{array}$ & Incidence \\
\hline $\begin{array}{l}\text { [37]Palmer, } 2012 \\
\text { (United States) }\end{array}$ & $\begin{array}{l}\text { The Black Women's Health Study, } \\
\text { baseline in } 1995 \text { with follow-up } \\
\text { through 2009; US Census } 2000\end{array}$ & $\begin{array}{l}\text { Longitudinal; Females; } 21-69 \\
\text { years at baseline; total } n=55,896, \\
\text { analysis on } n=1,343 \text { cases with } \\
\text { geocoded data; } 100 \% \text { black }\end{array}$ & $\begin{array}{l}17 \text { US states; Census block } \\
\text { group }\end{array}$ & $\begin{array}{l}\text { Composite SES (Based on median household } \\
\text { income, median housing value, \% household } \\
\text { receiving interest, dividends or net rental } \\
\text { income, \% with college degree, \% employed in } \\
\text { managerial, executive or professional specialty, } \\
\% \text { families with children headed by a single } \\
\text { female; categorized into quintiles) }\end{array}$ & Incidence \\
\hline $\begin{array}{l}\text { [38]Panczak, } 2012 \\
\text { (Switzerland) }\end{array}$ & $\begin{array}{l}\text { The Swiss National Cohort } \\
\text { 2001-2008;Swiss Census } 2000\end{array}$ & $\begin{array}{l}\text { Longitudinal; Females; } \geq 30 \text { years } \\
\text { old; } n=4,300,000 \text { (including } \\
\text { males), breast cancer deaths } \\
\text { unknown }\end{array}$ & $\begin{array}{l}\text { Switzerland; } \\
\text { Neighborhood boundaries }\end{array}$ & $\begin{array}{l}\text { Swiss-SEP Index (SES composite measure based } \\
\text { on occupational status, income, educational } \\
\text { attainment, family instability, persons living in } \\
\text { low standard housing likely to have difficulty } \\
\text { with English, categorized into deciles) }\end{array}$ & Mortality \\
\hline $\begin{array}{l}\text { [43]Schlichting, } 2012 \\
\text { (United States) }\end{array}$ & SEER 2000-2007; US Census 2000 & $\begin{array}{l}\text { Cross-sectional; Females } \\
\mathrm{n}=34,3627 \text { cases; } 75 \% \text { white, } 9 \% \\
\text { black, } 9 \% \text { Hispanic, } 7 \% \text { Asian/ } \\
\text { Pacific Islander, }<1 \% \text { American } \\
\text { Indian/ Native Alaskan }\end{array}$ & 17 SEER regions; County & $\begin{array}{l}\text { Education (\% without high school degree, } \\
\text { categorized into quartiles) Poverty (\% below } \\
\text { federal poverty level, categorized into three } \\
\text { groups }(<10 \%, 20-19 \%, \geq 20 \% \text { ) Urbanization } \\
\text { (Rural-urban continuum definition per US Dept. } \\
\text { of Agriculture, categorized into metro counties } \\
\text { and non-metro counties) }\end{array}$ & Incidence \\
\hline $\begin{array}{l}\text { [36]Markossian, } 2012 \\
\text { (United States) }\end{array}$ & SEER 1992-2007 & $\begin{array}{l}\text { Cross-sectional; Females; } \\
\geq 15 \text { years old; } \mathrm{n}=23,500 \text { cases; } \\
69 \% \text { white, } 31 \% \text { black }\end{array}$ & $\begin{array}{l}\text { Georgia ( } 15 \text { counties; } \\
\text { County }\end{array}$ & $\begin{array}{l}\text { Urban/Rural residence (County-level urban/rural } \\
\text { residence) }\end{array}$ & Mortality \\
\hline
\end{tabular}


zip code or postal code in 3 studies [27,42,44], enumeration districts in 2 studies [22,35], and local government area [23] and minor civil divisions [21] in one study each. Other studies used ABR measures corresponding to distance [29], neighborhood boundaries [38], SEER regions $[28,35]$, and one study had a priori specification of comparison counties [32]. County, census tract and block group level measures were predominant in U.S.based studies. With the exception of census tract used in the one study in Italy, other European and Australian studies relied on postal code, enumeration districts or local government area.

\section{Associations between ABR measures and breast cancer incidence}

The results of associations between $\mathrm{ABR}$ measures and breast cancer incidence by type of ABR measure are presented in Table 3 and Figure 2, and described in the next section.

\section{Education}

Of the four studies presenting results for ABR education, 3 studies reported higher incidence for the highest versus lowest ABR education [16,17,39]. The fourth study examined inflammatory breast cancer (IBC) and nonIBC separately, [43] and reported higher incidence of IBC in the lowest vs. highest ABR education, but consistent with positive associations between education and overall breast cancer, found lower non-IBC incidence in the lowest vs. highest ABR education. Three studies reported estimates of the association between ABR education and incidence for blacks and whites $[16,17,43]$. The associations appeared stronger in whites than in blacks in two studies $(\mathrm{RR}=1.33$ and 1.45 among whites, 1.10 and 1.19 among blacks) $[16,17]$; and the association was only statistically significant in white women in the study that reported statistical significance of the estimates [16]. Similarly, the remaining study reported slightly lower non-IBC incidence in the lowest versus highest ABR education in whites, $(\mathrm{RR}=0.96,95 \% \mathrm{CI}$ : 0.95-0.97) but found no significant ABR education differences in non-IBC risk for blacks ( $R R=1.00,95 \%$ CI: 0.97-1.03); however, for the rare IBC sub-type, incidence was higher in the lowest versus highest ABR education in both whites $(\mathrm{RR}=1.20,95 \% \mathrm{CI}: 1.09-1.32)$ and blacks $(\mathrm{RR}=1.28,95 \%$ CI: $1.04-1.58)$ [43].

\section{Meta analysis- education}

Two studies met the criteria for inclusion in the metaanalysis, shown in Figure $2[39,43]$, with one study presenting results for two subtypes of IBC and non-IBC. The meta-analysis summary RRs for the highest versus lowest ABR education was 1.05 (95\% CI: 0.93, 1.19). There was evidence of statistically significant heterogeneity between the studies $\left(\mathrm{P}<0.01 ; \mathrm{I}^{2}=97.2 \%\right)$, although there was no evidence of small-study bias as confirmed with Egger's test $(\mathrm{p}=0.25)$. Influence analysis indicated that the metaanalysis results were dominated by the non-IBC results presented by Schlichting et al., and excluding this study would have attenuated the observed associations. These two studies were the only studies eligible for meta-analysis that also presented race-stratified estimates for blacks and whites. The results of meta-analysis using the racestratified data yielded similar estimates with summary RR for the highest versus lowest ABR education of 1.05 (95\% CI: 0.87-1.27) among whites, and summary RR of 1.00 (95\% CI: 0.85-1.18) among blacks (data not shown).

\section{Income}

Five studies examined ABR income and incidence, and all reported higher incidence with higher ABR income $[16,17,27,35,39]$. The 2 studies with un-stratified estimates reported a statistically significant $15 \%$ higher breast cancer incidence associated with residence in higher ABR income areas [27,39]. Two studies reported estimates for whites and blacks, with both studies showing higher incidence for the highest versus lowest ABR income in whites (RRs of 1.37 and 1.29) [16,17], and one study showing the same association in blacks $(R R=1.59)[16]$; one study also reported a statistically significant $\mathrm{p}$-value for linear trend across categories of income in whites only [16]. One study evaluated ABR income and incidence in Ontario, Canada and in the U.S. [35], and reported positive and statistically significant association in both Canada $(\mathrm{RR}=1.10,95 \%$ CI: 1.04-1.16) and the U.S. ( $R R=1.35,95 \%$ CI: $1.31-1.40)$, with stronger associations in the U.S.

\section{Meta analysis- income}

Two studies met the criteria for inclusion in the metaanalysis [27,39]. The meta-analysis summary RRs for the highest versus lowest ABR income was 1.17 (95\% CI: $1.15,1.19)$. There was slight evidence of significant heterogeneity between the studies $\left(\mathrm{P}=0.23 ; \mathrm{I}^{2}=32.2 \%\right)$, and no evidence of small-study bias as confirmed with Egger's test $(\mathrm{p}=0.25)$.

\section{Poverty}

Seven studies presented results on ABR poverty $[4,19$, $20,30,39,43,46]$, of which three studies reported unstratified results $[30,39,43]$. Of these 3 studies, one reported lower breast cancer incidence in the lowest versus highest $\mathrm{ABR}$ poverty areas $(\mathrm{SIRR}=0.89,95 \% \mathrm{CI}$ : 0.80-0.99) [30], while another study observed the reverse for the same comparison $(\mathrm{RR}=1.11,95 \% \mathrm{CI}$ : 1.08-1.14) [39]. The remaining study reported higher incidence for IBC $(\mathrm{RR}=1.24,95 \% \mathrm{CI}: 1.12-1.37)$ and lower incidence for non-IBC $(R R=0.86,95 \% \mathrm{CI}$ : 0.84-0.87) in the highest versus lowest ABR poverty areas [43]. Four other 
Table 3 Summary of associations between residential environment and breast cancer incidence

\begin{tabular}{|c|c|c|c|c|c|}
\hline Author, year (location) & $\begin{array}{l}\text { Main area based } \\
\text { measure/contrast }\end{array}$ & $\begin{array}{l}\text { Stratification } \\
\text { variable }\end{array}$ & $\begin{array}{l}\text { Age-adjusted rates } \\
\text { per } 100,000\end{array}$ & Ratio measures & P-value trend \\
\hline \multicolumn{6}{|l|}{ Education } \\
\hline \multirow{2}{*}{$\begin{array}{l}\text { [17]Devesa, } 1980 \\
\text { (United States) }\end{array}$} & \multirow{2}{*}{$\begin{array}{l}\text { Highest vs. lowest } \\
\text { education }\end{array}$} & Whites & a 95.9 vs. 71.9 & b 1.33 & \\
\hline & & Blacks & a 52.0 vs. 43.8 & $\mathrm{~b}_{1.19}$ & \\
\hline \multirow{2}{*}{$\begin{array}{l}\text { [16]Baquet, } 1991 \\
\text { (United States) }\end{array}$} & \multirow{2}{*}{$\begin{array}{l}\text { Highest vs. lowest } \\
\text { education }\end{array}$} & White & 116 vs. 80.2 & b Rate Ratio: 1.45 & $<0.01$ \\
\hline & & Black & 77.4 vs. 70.3 & ${ }^{\mathrm{b}}$ Rate Ratio: 1.10 & 0.17 \\
\hline $\begin{array}{l}\text { [39]Prehn, } 1998 \text { (United } \\
\text { States) }\end{array}$ & $\begin{array}{l}\text { Highest vs. lowest } \\
\text { education }\end{array}$ & & & ${ }^{c}$ Rate Ratio: 1.18 (1.13-1.22) & \\
\hline \multirow[t]{3}{*}{$\begin{array}{l}\text { [43]Schlichting, } 2012 \\
\text { (United States) }\end{array}$} & \multirow[t]{3}{*}{$\begin{array}{l}\text { Lowest vs. highest } \\
\text { education }\end{array}$} & All races & & $\begin{array}{l}\text { ' Rate Ratio: IBC: } 1.20(1.12-1.30) \\
\text { Non-IBC: } 0.87(0.86-0.88)\end{array}$ & \\
\hline & & Non-Hispanic White & & $\begin{array}{l}\text { ' Rate Ratio: IBC: } 1.20 \text { (1.09-1.32) } \\
\text { Non-IBC: } 0.96(0.95-0.97)\end{array}$ & \\
\hline & & Black & & $\begin{array}{l}\text { ' Rate Ratio: IBC: } 1.28 \text { (1.04-1.58) } \\
\text { Non-IBC: } 1.00(0.97-1.03)\end{array}$ & \\
\hline \multicolumn{6}{|l|}{ Income } \\
\hline \multirow{2}{*}{$\begin{array}{l}\text { [17]Devesa, } 1980 \\
\text { (United States) }\end{array}$} & \multirow{2}{*}{$\begin{array}{l}\text { Highest vs. lowest } \\
\text { income }\end{array}$} & Whites & à93.4 vs. 68.4 & ${ }^{b} 1.37$ & \\
\hline & & Blacks & ${ }^{a} 48.2$ vs. 47.3 & $b_{1.02}$ & \\
\hline \multirow{2}{*}{$\begin{array}{l}\text { [16]Baquet, } 1991 \\
\text { (United States) }\end{array}$} & \multirow{2}{*}{$\begin{array}{l}\text { Highest vs. lowest } \\
\text { income }\end{array}$} & White & 104.3 vs. 80.7 & b Rate Ratio: 1.29 & $<0.01$ \\
\hline & & Black & 108.0 vs. 67.9 & b Rate Ratio: 1.59 & 0.27 \\
\hline $\begin{array}{l}\text { [39]Prehn, } 1998 \text { (United } \\
\text { States) }\end{array}$ & $\begin{array}{l}\text { Highest vs. lowest } \\
\text { income }\end{array}$ & & & ' Rate Ratio: 1.15 (1.11-1.19) & \\
\hline \multirow{2}{*}{$\begin{array}{l}\text { [35]Mackillop, } 2000 \\
\text { (Canada and United } \\
\text { States) }\end{array}$} & \multirow{2}{*}{$\begin{array}{l}\text { Highest vs. lowest } \\
\text { income }\end{array}$} & Ontario & & ' Rate Ratio: 1.10 (1.04-1.16) & \\
\hline & & US & & ' Rate Ratio: 1.35 (1.31-1.40) & \\
\hline $\begin{array}{l}\text { [27]Borugian, } 2011 \\
\text { (Canada) }\end{array}$ & $\begin{array}{l}\text { Lowest vs. highest } \\
\text { income }^{\S}\end{array}$ & & & ${ }^{`}$ Rate Ratio: 0.85 (0.84-0.86) & \\
\hline \multicolumn{6}{|l|}{ Poverty } \\
\hline \multirow[t]{8}{*}{$\begin{array}{l}\text { [20]Krieger, } 1990 \\
\text { (United States) }\end{array}$} & \multirow[t]{8}{*}{$\begin{array}{l}\text { Lowest vs. highest } \\
\text { poverty }\end{array}$} & $\begin{array}{l}\text { Black, }<40 \text { years, } \\
\text { High working class }\end{array}$ & 11.1 vs. 9.0 & b Rate Ratio: 1.23 & \\
\hline & & $\begin{array}{l}\text { Black, }<40 \text { years, } \\
\text { Low working class }\end{array}$ & 18.6 vs. 13.5 & ${ }^{\mathrm{b}}$ Rate Ratio: 1.38 & \\
\hline & & $\begin{array}{l}\text { Black, } \geq 40 \text { years, } \\
\text { High working class }\end{array}$ & 155.5 vs. 172.4 & ${ }^{\mathrm{b}}$ Rate Ratio: 0.90 & \\
\hline & & $\begin{array}{l}\text { Black, } \geq 40 \text { years, } \\
\text { Low working class }\end{array}$ & 238.7 vs. 256.8 & ${ }^{\mathrm{b}}$ Rate Ratio: 0.93 & \\
\hline & & $\begin{array}{l}\text { White, }<40 \text { years, } \\
\text { High working class }\end{array}$ & 9.0 vs. 14.0 & ${ }^{\mathrm{b}}$ Rate Ratio: 0.64 & \\
\hline & & $\begin{array}{l}\text { White, }<40 \text { years, } \\
\text { Low working class }\end{array}$ & 9.2 vs. 5.3 & ${ }^{\mathrm{b}}$ Rate Ratio: 1.74 & \\
\hline & & $\begin{array}{l}\text { White, } \geq 40 \text { years, } \\
\text { High working class }\end{array}$ & 214.7 vs. 209.9 & ${ }^{\mathrm{b}}$ Rate Ratio: 1.02 & \\
\hline & & $\begin{array}{l}\text { White, } \geq 40 \text { years, } \\
\text { Low working class }\end{array}$ & 248.8 vs. 284.8 & ${ }^{\mathrm{b}}$ Rate Ratio: 0.87 & \\
\hline $\begin{array}{l}\text { [30]Gorey, } 1998 \\
\text { (Canada) }\end{array}$ & $\begin{array}{l}\text { Lowest vs. highest } \\
\text { poverty }\end{array}$ & & 113.23 vs. 127.65 & $\begin{array}{l}\text { Standardized incidence rate } \\
\text { Ratio: } 0.89(0.80-0.99)\end{array}$ & \\
\hline $\begin{array}{l}\text { [39]Prehn, } 1998 \text { (United } \\
\text { States) }\end{array}$ & $\begin{array}{l}\text { Lowest vs. highest } \\
\text { poverty }\end{array}$ & & & ${ }^{c}$ Rate ratio: 1.11 (1.08-1.14) & \\
\hline \multirow[t]{2}{*}{$\begin{array}{l}\text { [46]Webster, } 2008 \\
\text { (United States) }\end{array}$} & \multirow[t]{2}{*}{$\begin{array}{l}\text { Lowest vs. highest } \\
\text { poverty }\end{array}$} & $\begin{array}{l}\text { Diagnosis year: } \\
1990\end{array}$ & & ${ }^{d} 1.27(0.85-1.92)$ & \\
\hline & & $\begin{array}{l}\text { Diagnosis year: } \\
1980\end{array}$ & & ${ }^{d} 0.94(0.59-1.48)$ & \\
\hline
\end{tabular}


Table 3 Summary of associations between residential environment and breast cancer incidence (Continued)

\begin{tabular}{|c|c|c|c|c|c|}
\hline \multirow[t]{2}{*}{$\begin{array}{l}\text { [4]Harper, } 2009 \text { (United } \\
\text { States) }\end{array}$} & \multirow[t]{2}{*}{$\begin{array}{l}\text { Highest vs. lowest } \\
\text { poverty }\end{array}$} & $\begin{array}{l}\text { Diagnosis Year: } \\
1987\end{array}$ & 328.7 vs. 381.6 & \multicolumn{2}{|l|}{${ }^{\mathrm{b}} 0.86$} \\
\hline & & $\begin{array}{l}\text { Diagnosis Year: } \\
2004\end{array}$ & 302.2 vs. 345.3 & \multicolumn{2}{|l|}{${ }^{\mathrm{b}} 0.88$} \\
\hline \multirow[t]{2}{*}{$\begin{array}{l}\text { [19]Hausauer, } 2009 \\
\text { (United States) }\end{array}$} & \multirow[t]{2}{*}{$\begin{array}{l}\text { Highest vs. lowest } \\
\text { poverty }\end{array}$} & $\begin{array}{l}\text { Diagnosis Year: } \\
2001\end{array}$ & $\begin{array}{l}337.6(326.2-349.2) \\
\text { vs. } 370.4(365.8- \\
375.1)\end{array}$ & \multicolumn{2}{|l|}{${ }^{b} 0.91$} \\
\hline & & $\begin{array}{l}\text { Diagnosis Year: } \\
2004\end{array}$ & $\begin{array}{l}305.1(294.5-316.1) \\
\text { vs. } 322.4(318.2- \\
\text { 326.6) }\end{array}$ & \multicolumn{2}{|l|}{ b 0.95} \\
\hline \multirow[t]{3}{*}{$\begin{array}{l}\text { [43]Schlichting, } 2012 \\
\text { (United States) }\end{array}$} & \multirow[t]{3}{*}{$\begin{array}{l}\text { Highest vs. lowest } \\
\text { poverty§ }\end{array}$} & All races & & \multicolumn{2}{|l|}{$\begin{array}{l}{ }^{c} \text { Rate Ratio: IBC: } 1.24 \text { (1.12-1.37) } \\
\text { Non-IBC: } 0.86(0.84-0.87)\end{array}$} \\
\hline & & Non-Hispanic white & & \multicolumn{2}{|l|}{$\begin{array}{l}\text { ` Rate Ratio: IBC: } 1.12(0.99-1.27) \\
\text { Non-IBC: } 0.87(0.86-0.89)\end{array}$} \\
\hline & & Black & & \multicolumn{2}{|l|}{$\begin{array}{l}\text { c Rate Ratio: IBC: } 1.32 \text { (1.01-1.72) } \\
\text { Non-IBC: } 1.02(0.98-1.06)\end{array}$} \\
\hline \multicolumn{6}{|l|}{ Composite SES } \\
\hline $\begin{array}{l}\text { [23]Williams, } 1991 \\
\text { (Australia) }\end{array}$ & \multicolumn{2}{|l|}{$\begin{array}{l}\text { Highest vs. lowest } \\
\text { SES }\end{array}$} & 203 vs. 146 & b Rate Ratio: 1.39 & $<0.001$ \\
\hline $\begin{array}{l}\text { [22]Pollock, } 1997 \\
\text { (United Kingdom) }\end{array}$ & \multicolumn{2}{|l|}{$\begin{array}{l}\text { Highest vs. lowest } \\
\text { SES }\end{array}$} & $\begin{array}{l}\text { SIR: } 105 \text { (95-115) vs. } \\
95 \text { (84-107) }\end{array}$ & \multicolumn{2}{|l|}{$\begin{array}{l}\text { b Standardized Incidence Rate } \\
\text { Ratio: } 1.11\end{array}$} \\
\hline $\begin{array}{l}\text { [34]Liu, } 1998 \text { (United } \\
\text { States) }\end{array}$ & \multicolumn{2}{|l|}{$\begin{array}{l}\text { Highest vs. lowest } \\
\text { SES }\end{array}$} & & c Relative Risk: 1.53 (1.49-1.57) & 0.0001 \\
\hline \multirow[t]{4}{*}{$\begin{array}{l}\text { [33]Krieger, } 1999 \\
\text { (United States) }\end{array}$} & \multirow{4}{*}{$\begin{array}{l}\text { Working class } \\
\text { poor vs. } \\
\text { Professional }\end{array}$} & \multicolumn{2}{|l|}{$\begin{array}{l}\text { Asian and Pacific } \\
\text { Islander }\end{array}$} & c Rate Ratio: 0.8 (0.7-1.0) & 0.07 \\
\hline & & \multicolumn{2}{|l|}{ Black } & ` Rate Ratio: 1.0 (0.9-1.1) & 0.89 \\
\hline & & \multicolumn{2}{|l|}{ Hispanic } & ${ }^{c}$ Rate Ratio: 0.5 (0.4-0.7) & 0.00 \\
\hline & & \multicolumn{2}{|l|}{ White } & ` Rate Ratio: 1.2 (1.1-1.3) & 0.12 \\
\hline \multirow{12}{*}{$\begin{array}{l}\text { [47]Yost, } 2001 \text { (United } \\
\text { States) }\end{array}$} & \multirow{12}{*}{$\begin{array}{l}\text { Highest vs. lowest } \\
\text { SES }\end{array}$} & \multicolumn{2}{|l|}{ Whites $15-49$ years } & $1.78(1.7-1.9)$ & $<0.0001$ \\
\hline & & \multicolumn{2}{|l|}{ Whites $50-64$ years } & $1.26(1.2-1.3)$ & $<0.0001$ \\
\hline & & \multicolumn{2}{|l|}{ Whites $65+$ years } & $1.21(1.2-1.3)$ & $<0.0001$ \\
\hline & & \multicolumn{2}{|l|}{ Blacks $15-49$ years } & $1.70(1.5-1.9)$ & 0.026 \\
\hline & & \multicolumn{2}{|l|}{ Blacks 50-64 years } & $1.20(1.1-1.4)$ & 0.008 \\
\hline & & Blacks $65+$ years & & $1.16(1.0-1.3)$ & 0.574 \\
\hline & & $\begin{array}{l}\text { Hispanics 15-49 } \\
\text { years }\end{array}$ & & $2.61(2.4-2.8)$ & $<0.0001$ \\
\hline & & $\begin{array}{l}\text { Hispanics 50-64 } \\
\text { years }\end{array}$ & & $1.85(1.7-2.0)$ & $<0.0001$ \\
\hline & & Hispanics $65+$ years & & $1.78(1.7-1.9)$ & $<0.0001$ \\
\hline & & $\begin{array}{l}\text { Asian/Others 15-49 } \\
\text { years }\end{array}$ & & $2.26(2.0-2.5)$ & 0.0001 \\
\hline & & $\begin{array}{l}\text { Asian/Others 50-64 } \\
\text { years }\end{array}$ & & $1.61(1.5-1.8)$ & 0.0016 \\
\hline & & $\begin{array}{l}\text { Asian/Others 65+ } \\
\text { years }\end{array}$ & & $1.54(1.4-1.7)$ & $<0.0001$ \\
\hline $\begin{array}{l}\text { [42]Robert, } 2004 \text { (United } \\
\text { States) }\end{array}$ & $\begin{array}{l}\text { Highest vs. lowest } \\
\text { SES }\end{array}$ & & & e Odds Ratios: 1.20 (1.05-1.37) & \\
\hline $\begin{array}{l}\text { [41]Reynolds, } 2005 \\
\text { (United States) }\end{array}$ & $\begin{array}{l}\text { Highest vs. lowest } \\
\text { SES }\end{array}$ & & & ` Rate Ratio: 1.59 (1.53-1.64) & $<0.01$ \\
\hline $\begin{array}{l}\text { [32]Krieger, } 2006 \\
\text { (United States) }\end{array}$ & $\begin{array}{l}\text { Highest vs. lowest } \\
\text { SES }\end{array}$ & $\begin{array}{l}\text { San Francisco Bay } \\
\text { Area }\end{array}$ & & $\begin{array}{l}{ }^{c} \text { IRR 1978-1982: } 1.23(1.10-1.38) \\
\text { 1988-1992: } 1.40(1.30-1.50) \text { 1998- } \\
\text { 2002: } 1.53(1.43-1.65)\end{array}$ & $\begin{array}{l}\text { 1978-1982: } p=0.000 ; \\
\text { 1988-1992: } p=0.000 ; \\
\text { 1998-2002 } p=0.000\end{array}$ \\
\hline
\end{tabular}


Table 3 Summary of associations between residential environment and breast cancer incidence (Continued)

\begin{tabular}{|c|c|c|c|c|c|}
\hline & & \multicolumn{2}{|l|}{$\begin{array}{l}\text { San Francisco Bay } \\
\text { Area, non-Hispanic } \\
\text { White }\end{array}$} & $\begin{array}{l}\text { C IRR 1978-1982: } 1.25 \text { (1.07-1.45) } \\
\text { 1988-1992: 0.96 (0.86-1.08) 1998- } \\
\text { 2002: } 1.21 \text { (1.06-1.38) }\end{array}$ & $\begin{array}{l}\text { 1978-1982: } p=0.001 ; \\
\text { 1988-1992: } \mathrm{p}=0.368 \\
\text { 1998-2002 } \mathrm{p}=.000\end{array}$ \\
\hline & & \multicolumn{2}{|l|}{$\begin{array}{l}\text { San Francisco Bay } \\
\text { Area, Black }\end{array}$} & $\begin{array}{l}\text { c IRR 1978-1982: } 0.82(0.34-1.99) \\
\text { 1988-1992: } 1.19(0.84-1.68) \text { 1998- } \\
\text { 2002: } 0.90(0.67-1.20)\end{array}$ & $\begin{array}{l}\text { 1978-1982: } p=0.159 ; \\
\text { 1988-1992: } p=0.192 ; \\
1998-2002 p=0.495\end{array}$ \\
\hline & & \multicolumn{2}{|l|}{ Los Angeles county } & $\begin{array}{l}{ }^{c} \text { IRR 1978-1982: } 1.51 \text { (1.40-1.63) } \\
\text { 1988-1992: 1.72 (1.64-1.81) 1998- } \\
\text { 2002: } 1.79(1.71-1.87)\end{array}$ & $\begin{array}{l}\text { 1978-1982: } p=0.000 ; \\
\text { 1988-1992: } p=0.000 ; \\
\text { 1998-2002 } p=0.000\end{array}$ \\
\hline & & \multicolumn{2}{|l|}{$\begin{array}{l}\text { Los Angeles } \\
\text { county, non- } \\
\text { Hispanic White }\end{array}$} & $\begin{array}{l}{ }^{c} \text { IRR 1978-1982: } 0.85 \text { (0.77-0.93) } \\
\text { 1988-1992: 1.16 (1.08-1.25) 1998- } \\
\text { 2002: } 1.19(1.11-1.26)\end{array}$ & $\begin{array}{l}\text { 1978-1982: } p=0.000 ; \\
\text { 1988-1992: } p=0.000 ; \\
\text { 1998-2002 } p=0.000\end{array}$ \\
\hline & & \multicolumn{2}{|l|}{$\begin{array}{l}\text { Los Angeles } \\
\text { county, Black }\end{array}$} & $\begin{array}{l}{ }^{c} \text { IRR 1978-1982: } 1.13(0.47-2.71) \\
\text { 1988-1992: 1.15 (0.82-1.60) 1998- } \\
\text { 2002: } 1.21(0.98-1.51)\end{array}$ & $\begin{array}{l}\text { 1978-1982: } p=0.027 \\
\text { 1988-1992: } p=0.000 ; \\
1998-2002 p=0.003\end{array}$ \\
\hline & & \multicolumn{2}{|l|}{ Massachusetts } & $\begin{array}{l}{ }^{c} \text { IRR 1988-1992: } 0.95 \text { (0.88-1.02) } \\
\text { 1998-2002: } 1.35(1.28-1.42)\end{array}$ & $\begin{array}{l}\text { 1988-1992: } p=0.020 ; \\
\text { 1998-2002 } p=0.000\end{array}$ \\
\hline & & \multicolumn{2}{|l|}{$\begin{array}{l}\text { Massachusetts, } \\
\text { non-Hispanic White }\end{array}$} & ${ }^{c}$ IRR 1998-2002: 1.14 (1.07-1.21) & 1998-2002: $p=0.000$ \\
\hline & & \multicolumn{2}{|l|}{$\begin{array}{l}\text { Massachusetts, } \\
\text { Black }\end{array}$} & $\begin{array}{l}{ }^{C} \text { IRR 1988-1992: } 0.80(0.35-1.83) \\
\text { 1998-2002: } 0.68(0.42-1.11)\end{array}$ & $\begin{array}{l}\text { 1988-1992: } 0=0.223 \\
1998-2002 p=0.911\end{array}$ \\
\hline $\begin{array}{l}\text { [44]Shack, } 2008 \text { (United } \\
\text { Kingdom) }\end{array}$ & $\begin{array}{l}\text { Lowest vs. highest } \\
\text { SES }^{\S}\end{array}$ & & & c $0.84(0.82-0.85)$ & \\
\hline \multirow[t]{2}{*}{$\begin{array}{l}\text { [46]Webster, } 2008 \\
\text { (United States) }\end{array}$} & \multirow[t]{2}{*}{$\begin{array}{l}\text { Highest vs. lowest } \\
\text { SES }\end{array}$} & \multicolumn{2}{|l|}{$\begin{array}{l}\text { Diagnosis year: } \\
1990\end{array}$} & d $1.30(0.86-1.96)$ & \\
\hline & & \multicolumn{2}{|l|}{$\begin{array}{l}10 \text { years prior to } \\
\text { diagnosis: } 1980\end{array}$} & d $1.69(1.10-2.59)$ & \\
\hline $\begin{array}{l}\text { [31]Keegan, } 2010 \\
\text { (United States) }\end{array}$ & $\begin{array}{l}\text { Highest vs. lowest } \\
\text { SES }\end{array}$ & & & c Rate Ratio: 1.79 (1.68-1.92) & \\
\hline [45]Spadea, 2010 (Italy) & $\begin{array}{l}\text { Lowest vs. highest } \\
\text { SES }\end{array}$ & & & ${ }^{f} 0.91(0.84-0.98)$ & \\
\hline $\begin{array}{l}\text { [37]Palmer, } 2012 \\
\text { (United States) }\end{array}$ & $\begin{array}{l}\text { Highest vs. lowest } \\
\text { SES }\end{array}$ & & & ${ }^{9}$ Rate Ratio: 0.92 (0.77-1.10) & 0.54 \\
\hline \multicolumn{6}{|l|}{ Occupational class } \\
\hline \multirow{4}{*}{$\begin{array}{l}\text { [20]Krieger, } 1990 \\
\text { (United States) }\end{array}$} & \multirow{4}{*}{$\begin{array}{l}\text { Highest vs. lowest } \\
\text { working class }\end{array}$} & \multicolumn{2}{|l|}{ Black, $<40$ years } & OR: $0.57(0.32-1.04)$ & \\
\hline & & \multicolumn{2}{|l|}{ Black, $\geq 40$ years } & OR: $0.68(0.53-0.88)$ & \\
\hline & & \multicolumn{2}{|l|}{ White, $<40$ years } & OR: 1.04 (0.82-1.32) & \\
\hline & & \multicolumn{2}{|l|}{ White, $\geq 40$ years } & OR: $0.86(0.81-0.92)$ & \\
\hline $\begin{array}{l}\text { [39]Prehn, } 1998 \text { (United } \\
\text { States) }\end{array}$ & $\begin{array}{l}\text { Lowest vs. highest } \\
\text { working class }\end{array}$ & & & c Rate Ratio: 1.13 (1.09-1.17) & \\
\hline \multicolumn{6}{|l|}{ Urbanization } \\
\hline $\begin{array}{l}\text { [21]Nasca, } 1992 \text { (United } \\
\text { States) }\end{array}$ & Urban vs. rural & & $\begin{array}{l}\text { SIR: } 107(104-110) \\
\text { vs. } 83(81-86)\end{array}$ & $\begin{array}{l}\text { b Standardized Incidence Rate } \\
\text { Ratio: } 1.29\end{array}$ & $<0.03$ \\
\hline $\begin{array}{l}\text { [40]Reynolds, } 2004 \\
\text { (United States) }\end{array}$ & $\begin{array}{l}\text { Urban vs. less } \\
\text { urban }\end{array}$ & & & e Hazard Ratio: 1.33 (1.10-1.62) & \\
\hline $\begin{array}{l}\text { [42]Robert, } 2004 \text { (United } \\
\text { States) }\end{array}$ & Urban vs. rural & & & e Odds Ratios: 1.17 (1.06-1.28) & \\
\hline \multirow{5}{*}{$\begin{array}{l}\text { [18]Hall, } 2005 \text { (United } \\
\text { States) }\end{array}$} & \multirow{2}{*}{$\begin{array}{l}\text { Metropolitan vs. } \\
\text { non-Metropolitan } \\
\text { non-adjacent }\end{array}$} & White & 122.7 vs. 104.0 & Rate Ratio: 1.18 & \\
\hline & & Non-White & 107.3 vs. 108.0 & Rate Ratio: 0.99 & \\
\hline & \multirow[t]{3}{*}{ Urban vs. rural } & White & 116.6 vs. 98.8 & b Rate Ratio: 1.18 & \\
\hline & & \multirow[t]{2}{*}{ Non-white } & 91.0 vs. 100.9 & ${ }^{\mathrm{b}}$ Rate Ratio: 0.90 & \\
\hline & & & & ${ }^{c}$ Rate Ratio: 0.98 (0.94-1.01) & \\
\hline
\end{tabular}


Table 3 Summary of associations between residential environment and breast cancer incidence (Continued)

\begin{tabular}{|c|c|c|c|c|}
\hline $\begin{array}{l}\text { [41]Reynolds, } 2005 \\
\text { (United States) }\end{array}$ & $\begin{array}{l}\text { Urban vs. small } \\
\text { town/rural }\end{array}$ & & & \\
\hline $\begin{array}{l}\text { [28]Clegg, } 2009 \text { (United } \\
\text { States) }\end{array}$ & Rural vs. urban ${ }^{\S}$ & & 157.6 vs. 147.1 & h $1.06(0.94-1.19)$ \\
\hline \multirow[t]{2}{*}{$\begin{array}{l}\text { [19]Hausauer, } 2009 \\
\text { (United States) }\end{array}$} & \multirow[t]{2}{*}{ Urban vs. rural } & $\begin{array}{l}\text { Diagnosis year: } \\
2001\end{array}$ & $\begin{array}{l}375.1(371.9-378.3) \\
\text { vs. } 306.2(292.9- \\
320.1)\end{array}$ & b 1.23 \\
\hline & & $\begin{array}{l}\text { Diagnosis year: } \\
2004\end{array}$ & $\begin{array}{l}323.5(320.6-326.4) \\
\text { vs. } 283.1(270.5- \\
295.1)\end{array}$ & b 1.14 \\
\hline \multirow[t]{3}{*}{$\begin{array}{l}\text { [43]Schlichting, } 2012 \\
\text { (United States) }\end{array}$} & \multirow[t]{3}{*}{$\begin{array}{l}\text { Non-metro vs. } \\
\text { metro }^{\S}\end{array}$} & All races & & $\begin{array}{l}\text { ` Rate Ratio: IBC: } 0.99 \text { (0.90-1.08) } \\
\text { Non-IBC: } 0.94 \text { (0.93-0.95) }\end{array}$ \\
\hline & & Non-Hispanic white & & $\begin{array}{l}{ }^{c} \text { Rate Ratio: IBC: } 0.95 \text { (0.85-1.05) } \\
\text { Non-IBC: } 0.88(0.87-0.89)\end{array}$ \\
\hline & & Black & & $\begin{array}{l}{ }^{C} \text { Rate Ratio: IBC: } 1.40(1.06-1.81) \\
\text { Non-IBC: } 0.97(0.92-1.01)\end{array}$ \\
\hline \multicolumn{5}{|l|}{ Hispanic enclave } \\
\hline \multirow[t]{2}{*}{$\begin{array}{l}\text { [31]Keegan, } 2010 \\
\text { (United States) }\end{array}$} & $\begin{array}{l}\text { Lowest enclave vs. } \\
\text { highest enclave }\end{array}$ & & & ` Rate Ratio: 1.79 (1.67-1.92) \\
\hline & $\begin{array}{l}\text { High SES low } \\
\text { enclave vs. low } \\
\text { SES high enclave }\end{array}$ & & & c Rate Ratio: 1.56 (1.50-1.63) \\
\hline \multicolumn{5}{|c|}{ Relative index of inequality } \\
\hline [45]Spadea, 2010 (Italy) & $\begin{array}{l}\text { Relative Index of } \\
\text { Inequality }\end{array}$ & & & ${ }^{\mathrm{f}} 0.92(0.82-1.02)$ \\
\hline \multicolumn{5}{|c|}{ Natural log of relative income } \\
\hline $\begin{array}{l}\text { [35]Mackillop, } 2000 \\
\text { (Canada and United } \\
\text { States) }\end{array}$ & $\begin{array}{l}\text { Natural log of } \\
\text { relative income for } \\
\text { regression }\end{array}$ & $\begin{array}{l}\text { Ontario } \\
\text { US }\end{array}$ & & $\begin{array}{l}\text { ` Rate Ratio: } 1.04 \text { (1.00-1.08) } \\
\text { ` Rate Ratio: } 1.14 \text { (1.12-1.17) }\end{array}$ \\
\hline \multicolumn{5}{|c|}{ 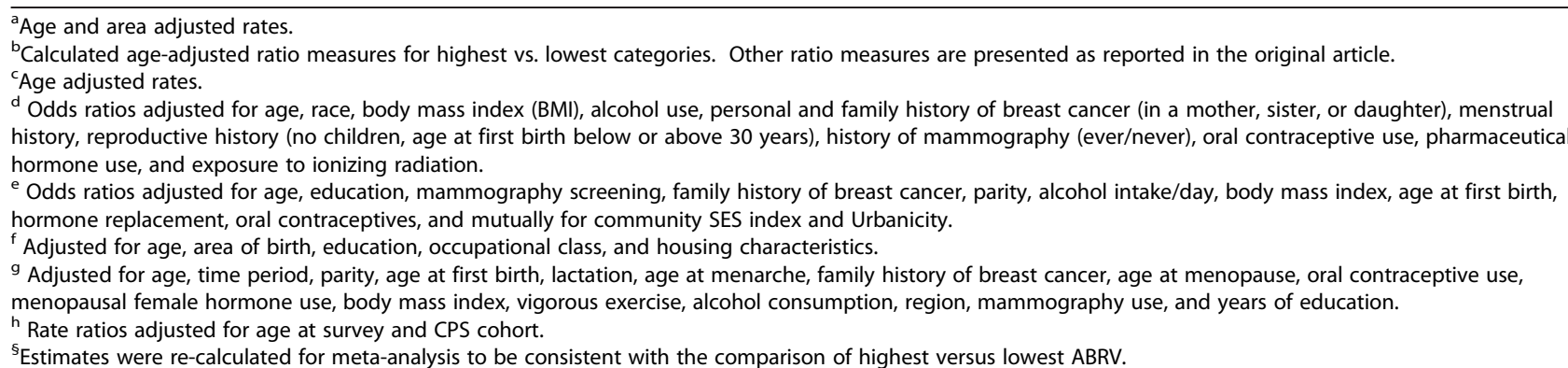 } \\
\hline
\end{tabular}

studies reported stratified results for ABR poverty and incidence $[4,19,20,30]$. One reported estimates across three levels of stratification by race, age and occupational class [20]. In black women less than 40 years old, lowest vs. highest $A B R$ poverty was associated with higher breast cancer incidence, regardless of ABR occupation class (RR for lowest vs. highest ABR poverty in high working class: 1.23, RR for lowest vs. highest ABR poverty in low working class: 1.38) whereas for white women less than 40 years old, lowest vs. highest ABR poverty was associated with higher incidence in low working class areas (RR for lowest vs. highest ABR poverty in low working class: 1.74) and associated with lower incidence in high working class areas (RR for lowest vs. highest $\mathrm{ABR}$ poverty in high working class: 0.64). In both white and black women over the age of 40 , lowest versus highest ABR poverty showed lower incidence or no differences in incidence. The remaining three studies reported results stratified by year of diagnosis $[4,19,46]$. Two studies that compared highest to lowest ABR poverty showed lower incidence in both years of studies considered $[4,19]$. The last study showed mixed and non-significant results across the two diagnosis years [46]. One study reported race-stratified results for IBC and non-IBC, and showed significantly lower non-IBC incidence in highest versus lowest ABR poverty areas for whites ( $R R=0.87,95 \% \mathrm{CI}$ : 0.86-0.89), nonsignificant results for blacks $(\mathrm{RR}=1.02$, 95\% CI: 0.98- 


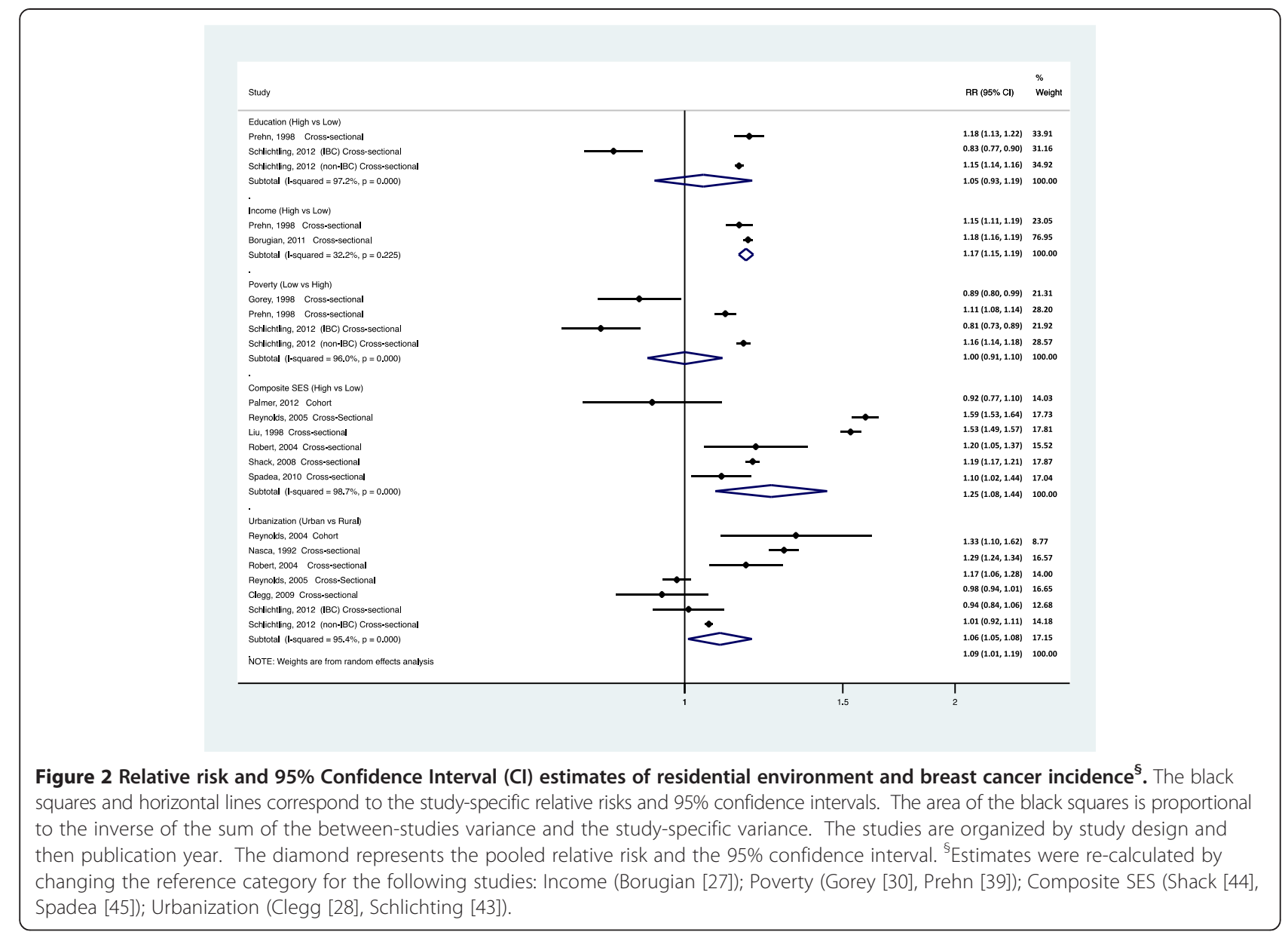

1.06), and non-significant associations for IBC in whites $(\mathrm{RR}=1.12$, 95\% CI: 0.99-1.27), but higher IBC incidence in blacks $(\mathrm{RR}=1.32,95 \% \mathrm{CI}: 1.01-1.72)^{33}$.

\section{Meta-analysis- poverty}

Three studies met the criteria for inclusion in the metaanalysis $[30,39,43]$. For consistency with other SES indicators (i.e. high SES vs. low SES), we compared low vs. high poverty areas as lower poverty areas represent higher SES areas. The meta-analysis summary RR for the lowest versus highest ABR poverty was 1.00 (95\% CI: 0.91-1.10). There was evidence of significant heterogeneity between the studies ( $\left.\mathrm{P}<0.01 ; \mathrm{I}^{2}=96.0 \%\right)$, but no evidence of small-study bias as confirmed with Egger's test $(\mathrm{P}=0.86)$. Influence analysis indicated that the meta-analysis results were dominated by the non-IBC results presented by Schlichting et al., and excluding this study would have attenuated the observed associations.

\section{Composite SES}

Thirteen studies presented results on ABR composite SES [22,23,31-34,37,41,42,44-47]. Of the 9 studies that reported un-stratified estimates [22,23,31,34,37,41,42,44,
45], 7 reported higher incidence in the highest versus lowest ABR composite SES [23,31,34,41,42,44,45], one showed a non-significant higher incidence [22], and one showed a non-significant lower incidence [37]. Two studies provided race-stratified estimates; one study used a combination of area based working class status and poverty as a measure of composite SES, and observed higher incidence among working class poor versus professionals whites ( $R R=1.2,95 \% \mathrm{CI}$ : 1.1-1.3), lower incidence among working class poor versus professionals Hispanics $(R R=$ 0.5, 95\% CI: 0.4-0.7), and non-significant differences in Asian and Pacific Islanders or blacks [33]. The other study reported race- and age-stratified estimates comparing the highest versus lowest ABR composite SES and showed significantly higher incidence in all age groups among whites, blacks, Hispanics and Asian/Others [47]. One study reported estimates stratified by region and time period [32]. In the San Francisco Bay Area, breast cancer incidence was higher for the highest versus lowest ABR composite SES in all three time periods, with rates increasing significantly from 1.23 (95\% CI: $1.10-1.38$ ) in 1978-1982 to 1.53 (95\% CI: 1.43-1.65) in 1998-2002. The higher incidence associated with higher composite SES was observed for 
white women in 1978-1982 ( $\mathrm{RR}=1.25$, 95\% CI: 1.07 $1.45)$ and $1998-2002$ ( $R R=1.21,95 \%$ CI: 1.06-1.38), but not for black women in any of the time periods. Similar patterns of higher breast cancer incidence in higher SES areas were observed in the same time period in Los Angeles County, and in1988-1992 and 1998-2002 in Massachusetts for the overall sample and white women, but these were not statistically significant for black women. Another study reported estimates stratified by diagnosis year, and showed higher but non-significant incidence for the highest versus lowest ABR composite SES in $1990(R R=1.30,0.86-1.96)$, and significantly higher incidence for the same contrast in $1980(\mathrm{RR}=1.69,95 \%$ CI: 1.10-2.59) [46].

\section{Meta-analysis- composite SES}

Seven studies met the criteria for inclusion in the metaanalysis $[31,34,37,41,42,44,45]$. The studies by Keegan et al. [31] and Reynolds et al. [41] both presented results for residential composite SES based on data from the same study population with overlap in the study period. We included the study by Reynolds in the meta-analysis since it had a larger sample size. The meta-analysis summary RR for the highest versus lowest residential composite SES for the six studies included in the metaanalysis was 1.25 (95\% CI: 1.08-1.44). There was evidence of significant heterogeneity between the studies $\left(\mathrm{P}<0.01, \mathrm{I}^{2}=98.7 \%\right)$, but no evidence of small-study bias as confirmed with Egger's test $(\mathrm{P}=0.74)$. We performed meta-regression analysis to identify potential sources of heterogeneity in the meta-analysis results adjusting for study year, study design (cross-sectional versus cohort) and adjustment for other covariates in the analysis. However, we found no evidence that these factors contributed to the observed heterogeneity in this meta-analysis. None of the variables were statistically significant in the analysis, and the between-study variance changed very slightly from 0.03 to 0.033 after adjusting for the covariates. Influence analysis indicated that the meta-analysis results were dominated by the results presented by Shack et al. [44] and Palmer et al. [37]. Excluding the Shack et al. study strengthened the observed association, while excluding the Palmer et al. study attenuated the observed associations.

\section{Occupational class}

Two studies presented results on ABR occupational class $[20,39]$, showing mostly lower incidence in the highest versus lowest $A B R$ working class. One study showed higher breast cancer incidence in the lowest versus highest $A B R$ working class ( $R R=1.13,95 \%$ CI: 1.09-1.17) [39]. The other study showed that among black women of all ages and among white women ages 40 years and older, breast cancer incidence was lower in highest versus lowest $A B R$ working class (ORs ranging between 0.57-0.86), but no differences by ABR occupational class were observed for white women less than 40 years $(\mathrm{OR}=1.04$, 95\% CI: 0.82-1.32) [20]. A summary estimate was not provided, as there were too few studies meeting the eligibility criteria for a meta-analysis.

\section{Urbanization}

Eight studies presented results on urbanization and incidence $[18,19,21,28,40-43]$. Six studies reported unstratified results [21,28,40-43], and 4 of these showed significantly higher breast cancer incidence ranging from $14 \%-33 \%$ in urban versus rural areas $[19,21,40,42]$. One study reported results for IBC and non-IBC; residing in a non-metropolitan versus metropolitan areas was associated with lower incidence of non-IBC ( $R R=0.94,95 \%$ CI: 0.93-0.95), while the association for IBC was not statistically significant [43]. Two studies presented estimates of the association between urbanization and incidence stratified by race $[18,43]$. In one study, incidence was higher in white women in metropolitan $(\mathrm{R} R=1.18$ relative to non-metropolitan area) and urban areas ( $R R=1.18$ relative to rural area), but no statistical test results were reported; results were less clear for nonwhite women [18]. In the other study [43], similar associations were observed for non-IBC, with incidence being lower among white women in non-metropolitan compared with metropolitan areas $(\mathrm{RR}=0.88,95 \% \mathrm{CI}$ : $0.87,0.89$ ), but differences were not statistically significant among black women $(R R=0.97,95 \%$ CI: $0.92,1.01)$. In contrast, IBC incidence among white women was not significantly different across metropolitan and non-metropolitan areas, but was significantly higher among black women in non-metropolitan versus metropolitan areas $(R R=1.40$, 95\% CI: 1.06, 1.81). Higher incidence was also reported in urban versus rural areas for diagnosis years 2001 $(\mathrm{RR}=1.23)$ and 2004 $(\mathrm{RR}=1.14)$ in another study [19].

\section{Meta-analysis- urbanization}

Six studies met the criteria for inclusion in the metaanalysis [21,28,40-43]. The meta-analysis summary RR comparing urban versus rural residence was 1.09 (95\% CI: 1.01-1.19). There was evidence of significant heterogeneity between the studies $\left(\mathrm{P}<0.01, \mathrm{I}^{2}=95.4 \%\right)$, but no evidence of small-study bias as confirmed with Egger's test $(\mathrm{P}=0.80)$. Influence analysis indicated that the metaanalysis results were dominated by the IBC results presented by Schlichting et al., and excluding this study would have strengthened the observed associations. We performed meta-regression analysis to identify potential sources of heterogeneity in the meta-analysis results adjusting for study year, study design (cross-sectional versus cohort) and adjustment for other covariates in the analysis. However, we found no evidence that these factors contributed to the observed heterogeneity in this 
meta-analysis. None of the variables were statistically significant in the analysis, and the between-study variance changed very slightly from 0.01 to 0.006 .

\section{Hispanic enclave}

One study presented results on ABR Hispanic enclave, and reported significantly higher incidence in lowest versus highest ABR Hispanic enclaves ( $R R=1.79,95 \% \mathrm{CI}$ : 1.67-1.92) [31]. Higher incidence was also observed in highest SES, low Hispanic enclave areas versus lowest SES, high enclave areas ( $R R=1.56,95 \%$ CI: $1.50-1.63)$.

\section{Other ABR measures}

One study computed a relative index of inequality, and showed a non-significant lower incidence with increasing $\mathrm{ABR}$ inequality ( $\mathrm{RR}=0.92,95 \% \mathrm{CI}$ : 0.82-1.02)[45]. Another study used the natural log of relative income in Ontario and the US [35], showing borderline statistically significant higher incidence with higher relative income in both countries (Ontario RR=1.04, 95\% CI: 1.00-1.08; US RR $=1.14,95 \%$ CI: $1.12-1.17$ ).

\section{Associations between ABR measures and breast cancer mortality}

The results of the associations between $A B R$ measures and breast cancer mortality by type of ABR measure are presented in Table 4 and described in detail below.

\section{Income}

One study presented results on ABR income, stratified by country region and population size [26]. Mortality was higher by $5-14 \%$ in the highest versus lowest $A B R$ income in all the strata, with the exception of U.S. Northeast areas with population size $>250,000(R R=0.99)$; however, no data on statistical tests was presented.

Table 4 Summary of associations between residential environment and breast cancer mortality

\begin{tabular}{|c|c|c|c|c|c|}
\hline Author, year (location) & $\begin{array}{l}\text { Main area based } \\
\text { measure/contrast }\end{array}$ & $\begin{array}{l}\text { Stratification } \\
\text { variable }\end{array}$ & $\begin{array}{l}\text { Age-adjusted rates } \\
\text { per } 100,000\end{array}$ & Ratio measures & P-value Trend \\
\hline \multicolumn{6}{|l|}{ Income } \\
\hline \multirow[t]{8}{*}{ [26]Blot, 1977 (United States) } & \multirow{8}{*}{$\begin{array}{l}\text { High income vs. low } \\
\text { income }\end{array}$} & Northeast, $<10,000$ & a 25.2 vs. 24.1 & & \\
\hline & & South, $<10,000$ & a 18.0 vs. 16.2 & ${ }^{\mathrm{b}}$ Rate Ratio: 1.05 & \\
\hline & & Central, $<10,000$ & a 22.0 vs. 20.9 & b Rate Ratio: 1.11 & \\
\hline & & West, $<10,000$ & a 20.7 vs. 20.3 & b Rate Ratio: 1.05 & \\
\hline & & Northeast, $250,000+$ & a 30.2 vs. 28.1 & ${ }^{\mathrm{b}}$ Rate Ratio: 0.99 & \\
\hline & & South, $250,000+$ & ${ }^{a} 25.1$ vs. 22.9 & ${ }^{\mathrm{b}}$ Rate Ratio: 1.07 & \\
\hline & & Central, 250,000+ & a 28.6 vs. 26.4 & b Rate Ratio: 1.08 & \\
\hline & & West, 250,000+ & a 26.8 vs. 23.6 & b Rate Ratio: 1.14 & \\
\hline \multicolumn{6}{|l|}{ Poverty } \\
\hline \multirow[t]{2}{*}{ [4]Harper, 2009 (United States) } & Highest vs. lowest SES & Year of death: 1987 & 85.1 vs. 102.7 & ${ }^{\mathrm{b}} 0.83$ & \\
\hline & & Year of death: 2004 & 76.3 vs. 74.4 & b 1.02 & \\
\hline \multicolumn{6}{|l|}{ Composite SES } \\
\hline [23]Williams, 1991 (Australia) & Highest vs. lowest SES & & a 68 vs. 57 & b Rate Ratio: 1.19 & \\
\hline $\begin{array}{l}\text { [22]Pollock, } 1997 \text { (United } \\
\text { Kingdom) }\end{array}$ & Highest vs. lowest SES & & $\begin{array}{l}\text { SMR: } 99(84-116) \\
\text { vs. } 111(93-132)\end{array}$ & b Rate Ratio: 0.89 & \\
\hline [38]Panczak, 2012 (Switzerland) & Lowest vs. highest SES & & & $\begin{array}{l}{ }^{c} \text { Hazard Ratio: } \\
0.96(0.87-1.05)\end{array}$ & 0.826 \\
\hline \multicolumn{6}{|l|}{ Urbanization } \\
\hline [29]Dobson, 2010 (Australia) & $\begin{array}{l}\text { Remote vs. major urban } \\
\text { centers }\end{array}$ & & & $\begin{array}{l}\text { d Hazard Ratio: } 0.47 \\
(0.06-3.42)\end{array}$ & \\
\hline $\begin{array}{l}\text { [36]Markossian, } 2012 \text { (United } \\
\text { States) }\end{array}$ & Rural vs. urban & & & $\begin{array}{l}\text { e Hazard Ratio: } \\
1.04(0.85-1.26)\end{array}$ & 0.748 \\
\hline
\end{tabular}

${ }^{a}$ Age adjusted rates.

${ }^{\mathrm{b}}$ Calculated age-adjusted ratio measures for highest vs. lowest categories. Other ratio measures are presented as reported in the original article.

c Adjusted for age, sex, nationality, marital status, level of urbanization, individual-level education and professional status.

${ }^{d}$ Age-adjusted hazard ratio.

${ }^{\text {e }}$ Adjusted for race, tumor stage, tumor grade, hormone receptor status and treatment (surgery/radiation). 


\section{Poverty}

One study examined ABR poverty and breast cancer mortality. Results were stratified by year of death [4], and reported lower mortality for highest versus lowest ABR poverty in $1987(\mathrm{RR}=0.83)$, and estimates approaching null in $2004(\mathrm{R}=1.02)$, but provided no data on statistical tests.

\section{Composite SES}

Three studies presented results on ABR composite SES $[22,23,38]$. Two studies showed higher mortality in highest versus lowest ABR composite SES, however one study did not provide data on statistical significance [23], and the other study was not statistically significant [22]. The third study reported lower mortality among residents of high ABR composite SES areas and the results were also not statistically significant [38].

\section{Urbanization}

Two studies presented results on urbanization, comparing rural or remote areas with urban areas $[29,36]$. One study reported non-significant lower mortality in remote areas (Hazard Ratio: 0.47, 95\% CI: 0.06-3.42) [29]. The second study reported a non-significant higher mortality (Hazard Ratio: 1.04, 95\% CI: 0.85-1.26) [36] in rural areas relative to urban areas with non-significant p-value for trend across levels of urbanization.

\section{Meta-analysis}

Two studies met the criteria for inclusion in the metaanalysis (figure not shown) [29,36]. The meta-analysis summary RR comparing urban versus rural residence was 0.97 (95\% CI: 0.79-1.18). There was no evidence of significant heterogeneity between the studies $(\mathrm{P}=0.44$, $\mathrm{I}^{2}=0.0 \%$ ), and no evidence of small-study bias as confirmed with Egger's test $(\mathrm{P}=0.62)$.

\section{Discussion}

This review and meta-analysis summarizes and quantifies the literature examining the association between a variety of constructs representing the residential environment and breast cancer incidence and mortality. There has been a substantial increase in the number of studies assessing the influence of the residential environment in relation to breast cancer in the past decade; over $30 \%$ of all studies on this topic were published in the past 3 years. Overall, residing in urban areas and in higher socioeconomic areas characterized by higher income, and composite SES was associated with higher breast cancer incidence. Specifically, the results from articles included in the meta-analysis showed that urban residence was associated with a borderline significant $9 \%$ increase in breast cancer incidence, and higher income and higher composite SES were respectively associated with a significant $17 \%$ and $25 \%$ increase in breast cancer incidence. The meta-analysis results for the association between higher education and lower poverty and increased breast cancer incidence appeared to have been attenuated due to the inverse associations between these variables and IBC incidence, a relatively rare type of cancer accounting for $<6 \%$ of all breast cancers diagnosed [49], and excluding IBC data from the meta-analysis resulted in statistically significant associations between higher breast cancer incidence and higher education and lower poverty. The associations between the residential environment and breast cancer mortality were less consistent across studies, with different studies showing both higher and lower mortality in urban vs. rural areas and in areas with high vs. low composite SES. We observed significant heterogeneity between studies included in both the systematic review as well as in the metaanalysis, which may be driven by differences in study design, construction of area level measures, and geographic units. Due to the observed heterogeneity between studies on breast cancer incidence, and the lack of statistical significance reporting in most of the studies on breast cancer mortality, the overall results should be interpreted with caution.

The positive association between ABR composite SES and breast cancer incidence was the strongest and most consistent association observed in this review. There is no clear consensus on the use of single SES indicators such as income or education versus summary or composite SES measures to characterize associations between socioeconomic status and health outcomes [50,51]. Both types of measures have been used extensively, and the decision regarding which type of measure to use should be driven by the research question of interest and hypothesized causal pathways. Measures of single SES indicators are often only modestly correlated, and may show associations of varying magnitude or direction with the same health outcomes [52]. In such cases, the use of a composite SES measure may result in null associations whereas the use of single SES indicators may provide insight into plausible pathways through which specific SES factors influence health. However, in the context of residential environment, the relationship between SES and health may not be driven solely by income, education or poverty per se, but instead may reflect exposure to complex and environments that are better captured through the use of a composite measure of SES.

Although our selection criteria did not specify geographic region, the majority of studies included in this review were conducted in the U.S., and thus the results may be more generalizable to the U.S. population. The positive association between residential composite SES and breast cancer incidence in the U.S. was also observed in studies from Australia, Canada and the U.K. 
The increase in breast cancer incidence associated with highest compared with lowest composite SES ranged from $20 \%$ in the U.K. and Canada to $40 \%$ in Australia. The similar associations observed in these countries with more inclusive social welfare and healthcare systems than those present in the U.S., including national healthcare insurance systems, which provide everyone with some level of access to healthcare, suggest the possibility of other pathways linking residential environment to breast cancer risk [53].

Potential pathways linking the residential environment with breast cancer risk or mortality include: physical attributes of an area that may promote or hinder breast cancer risk factors such as reproductive factors, diet and physical activity $[7,54,55]$; availability of resources relevant for screening and diagnoses such as access to mammogram facilities and clinics [10,11]; or psychosocial pathways involving stress and anxiety due to residential crime and safety [56,57]. The influence of these arealevel factors on breast cancer risk or mortality may be independent of individual-level factors including social status or health insurance, and the importance of investigating the potential mediating effect of individual-level factors in understanding how the residential environment operates in shaping health outcomes have previously been highlighted [58,59]. However, this topic remains largely unexplored in the literature included in this review as only 5 of the articles examined individuallevel breast cancer risk factors status $[37,40,42,45,46]$, and only 4 studies examined individual-level SES $[37,40,42,45]$. Of the 3 studies that controlled for an individual-level measure of SES in addition to an ABR SES measure $[37,42,45]$, two studies reported a $10-20 \%$ increase in breast cancer risk in the highest versus lowest composite SES areas after adjustment for individual-level educational status $[42,45]$, and one study, conducted only in black women, observed no significant association [37]. Overall, it is difficult to draw any conclusions about mechanisms or pathways of $A B R$ influences on breast cancer outcomes, as most of the studies included in the current review did not explicitly hypothesize or test a specific pathway through which the residential environment could influence breast cancer in women. As suggested by other reviews, many studies include area level constructs mainly as a proxy for missing individual-level factors that are known to influence breast cancer risk and mortality, which limit their interpretation in terms of residential or area level influences on breast cancer outcomes $[60,61]$.

With the exception of a few U.S. studies, the reviewed studies included populations comprised of predominantly white women. Several U.S. studies that presented results separately for black women or included substantial number of black women reported inconsistent and mostly non-significant associations in black women.
More research is needed to understand whether the associations between residential environment and breast cancer are consistent across U.S. racial/ethnic populations. Research in other countries with racial/ethnic diversity may also benefit from examining racial differences in the associations of ABR constructs and breast cancer outcomes as these may be different from those observed in the U.S.; however, availability of data on race/ethnicity in cancer surveillance data may be limited in certain countries.

The majority of reviewed studies employed a crosssectional design. For example, in most studies, breast cancer outcome and the residential environment construct were assessed contemporaneously, that is, there was no consideration given to the potential induction period between the exposure and diagnosis of breast cancer. The majority of the studies used administrative or secondary data sources (e.g. Census surveys) in developing ABR measures, while cancer registries (e.g. SEER) were the most common source of breast cancer data. The use of administrative data for ABR measures raises the issue of potential measurement error, since these databases were not designed for research purposes. There is also the issue of constantly changing geographic boundaries, which may result in misclassification if such changes are differential with respect to SES or other ABR measures. Finally, very few studies conducted multi-level analysis to account for the hierarchical nature of the data with individuals nested within neighborhoods. Further studies in this area should take advantage of the growing arsenal of methods available to deal with complex, multilevel studies such as structural equation models, Bayesian methods, and agentbased models.

There are several limitations in this review. The included studies were restricted to peer-reviewed, published, English language articles. The English language may have resulted in selection of large number of studies conducted in predominantly English-speaking countries including the U.S., Canada, U.K. and Australia. By restricting the search to studies that focused on breast cancer specifically, we may have missed studies with a more general title of 'cancer' during title review. However, we also searched the references of included articles, minimizing the likelihood of missing a significant number of studies. The review criteria resulted in the exclusion of articles that were focused on physical environmental exposures. We believed that the examination of physical environmental exposures (e.g. proximity to power lines) in relation to breast cancer constituted a separate class of exposures. As demonstrated in this review, studies included in the meta-analysis examined different $\mathrm{ABR}$ constructs and measurement. In addition to the heterogeneity in the exposure definition, individual studies examined different contrasts (e.g., quintiles, quartiles) and the same exposure contrast was not examined across the individual studies. We chose to 
include the most extreme contrast for this meta-analysis (e.g., highest vs. lowest category for comparison), which is standard practice in conducting a meta-analysis. However, the pooling of these contrasts could contribute to some of the between-studies heterogeneity that was observed for education, poverty, composite SES and urbanization, and it prevents us from examining the dose-response relationship between those exposures and the outcome. To identify potential sources of heterogeneity in the meta-analysis results based on study characteristics, we performed metaregression analysis; we observed no statistically significant evidence that factors such as year of publication, study design and multivariable adjustment contributed to the observed heterogeneity in this meta-analysis. Standardization of ABR measures across future studies should help to improve synthesis of findings and our understanding of residential environment influences on breast cancer outcomes.

There are also several strengths in this review. We used broad search criteria to improve our ability to select studies with a wide range of ABR measures, which may have been labeled differently across studies. In addition, the use of multiple ABR measures allowed us to examine relationships between different $A B R$ constructs in relation to breast cancer outcomes. The meta-analysis of similar studies allowed us to generate summary estimates of the magnitude of the association, information that has been lacking in this field. Although there was significant heterogeneity between studies within ABR constructs, the summary estimates provide a useful overview and highlights some gaps in the current published literature. This review imposed no restriction on geographic location of published studies. This is important to highlight differences and similarities in studies across countries, which may provide important information about potential effect modifiers (e.g. access to healthcare resources).

\section{Conclusions}

In conclusion, this is the first systematic review and metaanalysis of studies examining the associations between ABR constructs (income, education, poverty, composite SES, occupational class and urbanization) and breast cancer incidence and mortality. Lack of a priori specification of a conceptual model linking the residential environment with individual outcomes, inadequate considerations of temporality, inconsistencies in the geographic unit, lack of proper consideration of potential confounders and mediators, and lack of multi-level analytic techniques have all been identified as limitations in this field [58,60,61], and were the same limitations in most of the studies included in this review. Some of these limitations were further reflected in the statistically significant test for heterogeneity even between studies examining the same construct. While these conceptual and methodological issues limit our ability to draw definitive conclusions, we observed modest positive associations between breast cancer incidence residential area environment, as measured by ABR income and composite SES, and urbanization. Data from current studies did not allow for proper assessment of ABR measures in non-white women, but the limited data available for black women suggest less consistent associations between $\mathrm{ABR}$ measures and breast cancer incidence in black women. It is unclear whether the observed associations would remain once appropriate multi-level analytic methods with proper control for confounders are employed.

\section{Competing interests}

The authors declare that they have no competing interests.

\section{Authors' contributions}

TA participated in the design and coordination of the study, data collection, performed the statistical analysis, and led the writing of the manuscript. JG participated in the design and coordination of the study, oversaw the statistical analysis and contributed to the interpretation of the data and revision of the manuscript. MF participated in the coordination of the study, literature search, data collection and revision of the manuscript. AW participated in the coordination of the study and conducted literature search. TGW contributed to the design and coordination of the study, interpretation of the data and revision of the manuscript. PT conceived of the study, contributed to the study design and coordination, data collection and interpretation and writing of the manuscript. All authors read and approved the final manuscript.

\section{Authors' information}

Tiffany L. Gary-Webb and Parisa Tehranifar share joint senior authorship.

\section{Acknowledgements}

PT was supported by grants National Cancer Institute (CA K07 151777) and from the Susan G. Komen Foundation [KG110331]; TA was supported by a National Cancer Institute training grant [2-R25-CA-094061]; AW was supported by the Sally Casanova scholarship through the University of California Pre-doctoral program.

\section{Author details}

${ }^{1}$ Department of Epidemiology, Columbia University Mailman School of Public Health, New York, NY, USA. ${ }^{2}$ Herbert Irving Comprehensive Cancer Center, Columbia University Medical Center, New York, NY, USA. ${ }^{3}$ Department of Health Behavior and Health Education, University of Michigan School of Public Health, Ann Arbor, MI, USA. ${ }^{4}$ Departments of Community and Behavioral Sciences and Epidemiology, University of Pittsburgh Graduate School of Public Health, Pittsburgh, PA, USA.

Received: 10 September 2014 Accepted: 20 February 2015 Published online: 28 March 2015

\section{References}

1. US Surgeon General: Healthy People. The Surgeon General's Report on Health Promotion and Disease Prevention. In. Washington, DC: Public Health Service; 1979.

2. Office of Disease Prevention and Health Promotion: Healthy People 2010. In. Rockville, MD: US Department of Health and Human Services; 2000.

3. Mitchell KJ, Fritschi L, Reid A, McEvoy SP, Ingram DM, Jamrozik K, et al. Rural-urban differences in the presentation, management and survival of breast cancer in Western Australia. Breast. 2006;15(6):769-76.

4. Harper S, Lynch J, Meersman SC, Breen N, Davis WW, Reichman MC. Trends in area-socioeconomic and race-ethnic disparities in breast cancer incidence, stage at diagnosis, screening, mortality, and survival among women ages 50 years and over (1987-2005). Cancer epidemiology, biomarkers \& prevention : a publication of the American Association for Cancer Research, cosponsored by the American Society of Preventive Oncology 2009. 2009;18(1):121-31. 
5. Yu XQ. Socioeconomic disparities in breast cancer survival: relation to stage at diagnosis, treatment and race. BMC Cancer. 2009;9:364.

6. Tobler AL, Komro KA, Maldonado-Molina MM. Relationship between neighborhood context, family management practices and alcohol use among urban, multi-ethnic, young adolescents. Prevention science : the official journal of the Society for Prevention Research. 2009;10(4):313-24.

7. Mohnen SM, Volker B, Flap H, Groenewegen PP. Health-related behavior as a mechanism behind the relationship between neighborhood social capital and individual health-a multilevel analysis. BMC Public Health. 2012;12:116.

8. Burdette AM. Neighborhood context and breastfeeding behaviors among urban mothers. Journal of human lactation : official journal of International Lactation Consultant Association. 2013;29(4):597-604.

9. Auchincloss AH, Mujahid MS, Shen M, Michos ED, Whitt-Glover MC, Diez Roux AV. Neighborhood health-promoting resources and obesity risk (the multi-ethnic study of atherosclerosis). Obesity. 2013;21(3):621-8.

10. Elkin EB, Ishill NM, Snow JG, Panageas KS, Bach PB, Liberman L, et al. Geographic access and the use of screening mammography. Med Care. 2010;48(4):349-56.

11. Coughlin SS, Leadbetter S, Richards T, Sabatino SA. Contextual analysis of breast and cervical cancer screening and factors associated with health care access among United States women, 2002. Soc Sci Med. 2008;66(2):260-75.

12. Akinyemiju TF, Soliman AS, Johnson NJ, Altekruse SF, Welch K, Banerjee M, et al. Individual and neighborhood socioeconomic status and healthcare resources in relation to black-white breast cancer survival disparities. Journal of cancer epidemiology. 2013;2013:490472.

13. Du XL, Fang S, Meyer TE. Impact of treatment and socioeconomic status on racial disparities in survival among older women with breast cancer. Am J Clin Oncol. 2008;31(2):125-32.

14. Diez Roux AV. A glossary for multilevel analysis. J Epidemiol Community Health. 2002;56(8):588-94.

15. Centre for Reviews and Dissemination: Systematic Reviews. CRD's guidance for undertaking reviews in health care. In. York, UK: University of York; 2009.

16. Baquet CR, Horm JW, Gibbs T, Greenwald P. Socioeconomic factors and cancer incidence among blacks and whites. J Natl Cancer Inst. 1991;83(8):551-7.

17. Devesa SS, Diamond EL. Association of breast cancer and cervical cancer incidence with income and education among whites and blacks. J Natl Cancer Inst. 1980;65(3):515-28.

18. Hall SA, Kaufman JS, Millikan RC, Ricketts TC, Herman D, Savitz DA Urbanization and breast cancer incidence in North Carolina, 1995-1999. Ann Epidemiol. 2005;15(10):796-803.

19. Hausauer AK, Keegan TH, Chang ET, Glaser SL, Howe H, Clarke CA. Recent trends in breast cancer incidence in US white women by county-level urban/rural and poverty status. BMC Med. 2009;7:31.

20. Krieger N. Social class and the black/white crossover in the age-specific incidence of breast cancer: a study linking census-derived data to population-based registry records. Am J Epidemiol. 1990;131(5):804-14.

21. Nasca PC, Mahoney MC, Wolfgang PE. Population density and cancer incidence differentials in New York State, 1978-82. Cancer causes \& control : CCC. 1992;3(1):7-15.

22. Pollock AM, Vickers N. Breast, lung and colorectal cancer incidence and survival in South Thames Region, 1987-1992: the effect of social deprivation. J Public Health Med. 1997;19(3):288-94.

23. Williams J, Clifford C, Hopper J, Giles G. Socioeconomic status and cancer mortality and incidence in Melbourne. Eur J Cancer. 1991;27(7):917-21.

24. DerSimonian R, Laird N. Meta-analysis in clinical trials. Control Clin Trials. 1986;7(3):177-88.

25. Stram DO. Meta-analysis of published data using a linear mixed-effects model. Biometrics. 1996;52(2):536-44.

26. Blot WJ, Fraumeni Jr JF, Stone BJ. Geographic patterns of breast cancer in the United States. J Natl Cancer Inst. 1977;59(5):1407-11.

27. Borugian MJ, Spinelli JJ, Abanto Z, Xu CL, Wilkins R. Breast cancer incidence and neighbourhood income. Health reports/Statistics Canada, Canadian Centre for Health Information = Rapports sur la sante/Statistique Canada, Centre canadien d'information sur la sante. 2011:22(2):7-13.

28. Clegg LX, Reichman ME, Miller BA, Hankey BF, Singh GK, Lin YD, et al. Impact of socioeconomic status on cancer incidence and stage at diagnosis: selected findings from the surveillance, epidemiology, and end results: National Longitudinal Mortality Study. Cancer causes \& control : CCC. 2009;20(4):417-35.
29. Dobson A, McLaughlin D, Vagenas D, Wong KY. Why are death rates higher in rural areas? Evidence from the Australian Longitudinal Study on Women's Health. Aust N Z J Public Health. 2010;34(6):624-8.

30. Gorey KM, Holowaty EJ, Laukkanen E, Fehringer G, Richter NL. Association between socioeconomic status and cancer incidence in Toronto, Ontario: possible confounding of cancer mortality by incidence and survival. Cancer prevention \& control : CPC = Prevention \& controle en cancerologie : PCC. 1998;2(5):236-41.

31. Keegan TH, John EM, Fish KM, Alfaro-Velcamp T, Clarke CA, Gomez SL. Breast cancer incidence patterns among California Hispanic women: differences by nativity and residence in an enclave. Cancer Epidemiol Biomarkers Prev. 2010;19(5):1208-18.

32. Krieger N, Chen JT, Waterman PD, Rehkopf DH, Yin R, Coull BA. Race/ ethnicity and changing US socioeconomic gradients in breast cancer incidence: California and Massachusetts, 1978-2002 (United States). Cancer causes \& control : CCC. 2006;17(2):217-26.

33. Krieger N, Quesenberry Jr C, Peng T, Horn-Ross P, Stewart S, Brown S, et al. Social class, race/ethnicity, and incidence of breast, cervix, colon, lung, and prostate cancer among Asian, Black, Hispanic, and White residents of the San Francisco Bay Area, 1988-92 (United States). Cancer causes \& control : CCC. 1999;10(6):525-37.

34. Liu L, Deapen D, Bernstein L. Socioeconomic status and cancers of the female breast and reproductive organs: a comparison across racial/ethnic populations in Los Angeles County, California (United States). Cancer causes \& control : CCC. 1998;9(4):369-80.

35. Mackillop WJ, Zhang-Salomons J, Boyd CJ, Groome PA. Associations between community income and cancer incidence in Canada and the United States. Cancer. 2000;89(4):901-12.

36. Markossian TW, Hines RB. Disparities in late stage diagnosis, treatment, and breast cancer-related death by race, age, and rural residence among women in Georgia. Women Health. 2012;52(4):317-35.

37. Palmer JR, Boggs DA, Wise LA, Adams-Campbell LL, Rosenberg L. Individual and neighborhood socioeconomic status in relation to breast cancer incidence in African-American women. Am J Epidemiol. 2012;176(12):1141-6.

38. Panczak R, Galobardes B, Voorpostel M, Spoerri A, Zwahlen M, Egger M, et al. A Swiss neighbourhood index of socioeconomic position: development and association with mortality. J Epidemiol Community Health. 2012;66(12):1129-36.

39. Prehn AW, West DW. Evaluating local differences in breast cancer incidence rates: a census-based methodology (United States). Cancer causes \& control : CCC. 1998;9(5):511-7.

40. Reynolds P, Hurley S, Goldberg DE, Anton-Culver H, Bernstein L, Deapen D, et al. Regional variations in breast cancer among california teachers. Epidemiology. 2004;15(6):746-54.

41. Reynolds P, Hurley SE, Quach AT, Rosen H, Von Behren J, Hertz A, et al. Regional variations in breast cancer incidence among California women, 1988-1997. Cancer causes \& control : CCC. 2005;16(2):139-50.

42. Robert SA, Strombom I, Trentham-Dietz A, Hampton JM, McElroy JA, Newcomb PA, et al. Socioeconomic risk factors for breast cancer: distinguishing individual- and community-level effects. Epidemiology. 2004;15(4):442-50.

43. Schlichting JA, Soliman AS, Schairer C, Banerjee M, Rozek LS, Schottenfeld D, et al. Association of inflammatory and noninflammatory breast cancer with socioeconomic characteristics in the Surveillance, Epidemiology, and End Results database 2000-2007. Cancer epidemiology, biomarkers \& prevention : a publication of the American Association for Cancer Research, cosponsored by the American Society of Preventive Oncology 2012. 2012;21(1):155-65.

44. Shack L, Jordan C, Thomson CS, Mak V, Moller H, Registries UKAC. Variation in incidence of breast, lung and cervical cancer and malignant melanoma of skin by socioeconomic group in England. BMC Cancer. 2008:8:271.

45. Spadea T, Zengarini N, Kunst A, Zanetti R, Rosso S, Costa G. Cancer risk in relationship to different indicators of adult socioeconomic position in Turin, Italy. Cancer causes \& control : CCC. 2010;21(7):1117-30.

46. Webster TF, Hoffman K, Weinberg J, Vieira V, Aschengrau A. Community- and individual-level socioeconomic status and breast cancer risk: multilevel modeling on Cape Cod, Massachusetts. Environ Health Perspect. 2008;116(8):1125-9.

47. Yost K, Perkins C, Cohen R, Morris C, Wright W. Socioeconomic status and breast cancer incidence in California for different race/ethnic groups. Cancer causes \& control : CCC. 2001;12(8):703-11. 
48. Morris R, Carstairs V. Which deprivation? A comparison of selected deprivation indexes. J Public Health Med. 1991;13(4):318-26.

49. Anderson WF, Schairer C, Chen BE, Hance KW, Levine PH. Epidemiology of inflammatory breast cancer (IBC). Breast Dis. 2005;22:9-23.

50. Shavers VL. Measurement of socioeconomic status in health disparities research. J Natl Med Assoc. 2007;99(9):1013-23.

51. Braveman P, Cubbin C, Marchi K, Egerter S, Chavez G. Measuring socioeconomic status/position in studies of racial/ethnic disparities: maternal and infant health. Public Health Rep. 2001;116(5):449-63.

52. Braveman PA, Cubbin C, Egerter S, Chideya S, Marchi KS, Metzler M, et al. Socioeconomic status in health research: one size does not fit all. JAMA. 2005;294(22):2879-88.

53. Brown S, Castelli M, Hunter DJ, Erskine J, Vedsted P, Foot C, et al. How might healthcare systems influence speed of cancer diagnosis: A narrative review. Soc Sci Med. 2014;116C:56-63.

54. Humpel N, Owen N, Leslie E. Environmental factors associated with adults' participation in physical activity: a review. Am J Prev Med. 2002;22(3):188-99.

55. Gordon C, Purciel-Hill M, Ghai NR, Kaufman L, Graham R, Van Wye G. Measuring food deserts in New York City's low-income neighborhoods. Health Place. 2011;17(2):696-700

56. Steptoe A, Feldman PJ. Neighborhood problems as sources of chronic stress: development of a measure of neighborhood problems, and associations with socioeconomic status and health. Annals of behavioral medicine : a publication of the Society of Behavioral Medicine. 2001;23(3):177-85.

57. Feldman PJ, Steptoe A. How neighborhoods and physical functioning are related: the roles of neighborhood socioeconomic status, perceived neighborhood strain, and individual health risk factors. Annals of behavioral medicine : a publication of the Society of Behavioral Medicine. 2004;27(2):91-9.

58. Jackson N, Denny S, Ameratunga S. Social and socio-demographic neighborhood effects on adolescent alcohol use: A systematic review of multi-level studies. Soc Sci Med. 2014;115C:10-20.

59. Diez-Roux AV. Bringing context back into epidemiology: variables and fallacies in multilevel analysis. Am J Public Health. 1998;88(2):216-22.

60. Pruitt SL, Shim MJ, Mullen PD, Vernon SW, Amick 3rd BC. Association of area socioeconomic status and breast, cervical, and colorectal cancer screening: a systematic review. Cancer epidemiology, biomarkers \& prevention : a publication of the American Association for Cancer Research, cosponsored by the American Society of Preventive Oncology. 2009;18(10):2579-99.

61. Vainshtein J. Disparities in breast cancer incidence across racial/ethnic strata and socioeconomic status: a systematic review. J Natl Med Assoc. 2008;100(7):833-9.

\section{Submit your next manuscript to BioMed Central and take full advantage of:}

- Convenient online submission

- Thorough peer review

- No space constraints or color figure charges

- Immediate publication on acceptance

- Inclusion in PubMed, CAS, Scopus and Google Scholar

- Research which is freely available for redistribution 